\title{
Inhibition of Bacteria Associated with Wound Infection by Biocompatible Green Synthesized Gold Nanoparticles from South African Plant Extracts
}

\author{
Abdulrahman M. Elbagory ${ }^{1}$, Mervin Meyer ${ }^{1}$, Christopher N. Cupido ${ }^{2}$ \\ and Ahmed A. Hussein ${ }^{3, *}$ (10) \\ 1 DST/Mintek Nanotechnology Innovation Centre, Department of Biotechnology, \\ University of the Western Cape, Private Bag X17, Bellville 7535, South Africa; \\ 3376881@myuwc.ac.za (A.M.E.); memeyer@uwc.ac.za (M.M.) \\ 2 Botany Department, University of Forte Hare, Private Bag X1314, Alice 5700, South Africa; \\ ccupido@ufh.ac.za \\ 3 Chemistry Department, Cape Peninsula University of Technology, P.O. Box 1906, Bellville 7535, South Africa \\ * Correspondence: mohammedam@cput.ac.za; Tel.: +27-21-9596193
}

Received: 11 October 2017; Accepted: 10 November 2017; Published: 26 November 2017

\begin{abstract}
Unlike conventional physical and chemical methods, the biogenic synthesis of gold nanoparticles (GNPs) is considered a green and non-toxic approach to produce biocompatible GNPs that can be utilized in various biomedical applications. This can be achieved by using plant-derived phytochemicals to reduce gold salt into GNPs. Several green synthesized GNPs have been shown to have antibacterial effects, which can be applied in wound dressings to prevent wound infections. Therefore, the aim of this study is to synthesize biogenic GNPs from the South African Galenia africana and Hypoxis hemerocallidea plants extracts and evaluate their antibacterial activity, using the Alamar blue assay, against bacterial strains that are known to cause wound infections. Additionally, we investigated the toxicity of the biogenic GNPs to non-cancerous human fibroblast cells (KMST-6) using 3-[4,5-dimethylthiazol-2-yl]-2,5-diphenyl tetrazolium bromide (MTT) assay. In this paper, spherical GNPs, with particle sizes ranging from 9 to $27 \mathrm{~nm}$, were synthesized and fully characterized. The GNPs from $H$. hemerocallidea exhibited antibacterial activity against all the tested bacterial strains, whereas GNPs produced from G. africana only exhibited antibacterial activity against Pseudomonas aeruginosa. The GNPs did not show any significant toxicity towards KMST-6 cells, which may suggest that these nanoparticles can be safely applied in wound dressings.
\end{abstract}

Keywords: gold nanoparticles; green nanotechnology; Galenia africana; Hypoxis hemerocallidea; antibacterial activity; Alamar blue; MTT; HRTEM

\section{Introduction}

The antibacterial potential of the metallic nanoparticles (NPs) have been under investigation to counter the increase of microbial resistance against the current antimicrobial agents [1]. Additionally, the potential application of the NPs in wound dressings to fight infections makes these NPs extremely useful in wound care. Different metals such as gold, silver, platinum, palladium, copper, aluminum, iron, and titanium have been used to synthesize NPs [2]. Gold nanoparticles (GNPs) in particular have attracted huge attention for their unique optical properties as well as their biocompatibility [1]. GNPs are included in a variety of applications such as separation science [3], optical sensors, food industry as well as space and environmental sciences [4]. GNPs have also shown potential in several biomedical applications. GNPs have been shown to destroy tumors by photothermal therapy [5]. Other biomedical applications of GNPs include gene therapy, drug delivery, DNA and RNA analysis and as antibacterial agents, etc. [6]. 
The use of environmentally toxic reagents, the production of harmful by-products and the use of expensive apparatus during conventional physical and chemical synthesis of metallic NPs hinder their exploitation in biomedical applications. Conversely, the green synthesis of metallic NPs involves the use of safe biological reagents that produce biocompatible NPs using cost effective methods [7]. GNPs have been successfully synthesized from different biological sources such as proteins, flagella, bacteria and fungi [8-11]. Among these biological entities, plant extracts are extensively used in the synthesis of GNPs, because they are easier to handle, more readily available, cheaper and safer compared to the other aforementioned biological sources [7,12-16]. The synthesis of metal NPs using plant extracts is mediated through the presence of numerous reducing phytochemicals such as proteins, amines, phenols, carboxylic acids, ketones, aldehydes, etc. [17].

Several studies have reported the antimicrobial activities of biogenic GNPs. GNPs synthesized from natural honey exhibited significant antibacterial activity against pathogenic bacteria including multi-drug resistant bacterial strains [18]. Ayaz Ahmed et al. (2014) reported a potent antibacterial activity against several pathogenic bacteria such as Pseudomonas aeruginosa and Escherichia coli for the GNPs synthesized from the Indian plant, Salicornia brachiata [19]. E. coli and Staphylococcus aureus were also found to be sensitive to GNPs synthesized from Mentha piperita [20]. The synthesis of GNPs using extracts produced from plants with known antibacterial activities can potentially produce NPs with significant antibacterial activities.

Galenia africana L. var. africana, locally known as "kraalbos" or "geelbos", is a common plant found throughout Namaqualand, South Africa [21]. This plant is used to treat venereal sores, asthma, coughs and eye infections. Indigenous tribes use the leaves from this plant to relieve toothache [22]. Hypoxis hemerocallidea is also an important medicinal plant that is indigenous to South Africa. Its corms are used in traditional medicine to treat psychiatric disturbances and as a diuretic. It is also used to kill small vermin and to treat gall sickness in cattle [23]. The infusion of this plant is widely exploited by the Zulu tribe to cure impotency [24]. Moreover, the extracts of H. hemerocallidea are used to treat many diseases including diabetes, urinary infections, cancer and in the management of Human Immunodeficiency Virus infection and Acquired Immune Deficiency Syndrome HIV/AIDS [25]. In addition to these medicinal uses, both G. africana and H. hemerocallidea plants are also known for their wound healing properties. A lotion from G. africana decoction is used to alleviate inflammation and to treat skin diseases [26]. H. hemerocallidea extracts can be applied topically to relieve skin wounds and rashes [27].

Microbial infections can deter the wound healing process as microbial pathogens can reduce the number of fibroblasts and collagen regeneration via activation of inflammatory mediators as a result of the production of microbial toxins [28]. Therefore, an ideal wound-healing agent should demonstrate antimicrobial activity. Both G. africana and H. hemerocallidea exhibited antibacterial activity, which could be potentially beneficial for wound healing. The 5,7,2-trihydroxyflavone isolated from G. africana has been found to have antibacterial activity against Mycobacterium smegmatis and Mycobacterium tuberculosis [29]. The acetone and the ethanolic extracts of $H$. hemerocallidea have been shown antibacterial activities against $S$. aureus. Also, different extracts of $H$. hemerocallidea exhibited efficient antibacterial activity against several bacterial strains. This activity was enhanced when the extracts of $H$. hemerocallidea were combined with other medicinal plant extracts [30]. All these studies demonstrate that the extracts of G. africana and H. hemerocallidea plants contain phytochemicals with antibacterial activity that could aid in the wound healing process.

In this paper, GNPs were synthesized from the aqueous extracts of G. africana and H. hemerocallidea. The synthesis of GNPs was monitored using Ultraviolet-Visible Spectroscopy (UV-Vis). The hydrodynamic size measurement of the GNPs was done using Dynamic Light Scattering (DLS). The GNPs' morphology and their crystalline nature were inspected using High Resolution Transmission Electron Microscopy (HRTEM). Energy-Dispersive X-ray spectroscopy (EDX) was utilized to confirm the presence of the elemental gold in the GNPs. Additionally, the possible chemical functional groups involved in the biosynthesis of the GNPs were identified using Fourier Transform Infrared spectroscopy (FTIR). 
Thermogravimetric analysis (TGA) was also done to get an estimation of the amount of organic layer that surrounds the GNPs. The growth kinetics of the GNPs was also studied. The stability of the GNPs was measured in different biological buffer solutions. The in vitro toxicity of the synthesized GNPs was evaluated on non-cancerous human fibroblast cell line (KMST-6). The antibacterial evaluation of the GNPs and the extracts against several gram-positive and gram-negative bacteria was performed.

\section{Results and Discussion}

In order to produce GNPs chemically, a reducing agent is normally added to the gold salt to reduce gold atoms and allowing them to grow into GNPs. The addition of other organic molecules can be done to surround the GNPs in order to control their growth, prevent their aggregation and increase their stability [31].

The ability of G. africana and H. hemerocallidea plant extracts to provide secondary metabolites, not only capable of reducing the gold salt but also able to provide stabilization (capping) properties, was examined. The shape, distribution, morphology and surface charges of the GNPs were studied. The study also evaluated the biocompatibility and antibacterial activity of the GNPs.

This study follows on from a previous report in which extracts from several indigenous South African plants were screened for the biosynthesis of GNPs using a quick and easy microtitre plate method [32]. The previously reported methodology was applied here in order to obtain the optimum concentration for each plant extract (as mentioned in Section 3) that can produce the smallest and most defined GNPs. In the previous report, it was also concluded that the use of high temperature facilitates the synthesis of smaller GNPs. Hence, the synthesis of the GNPs in the current study was done at $70{ }^{\circ} \mathrm{C}$.

\subsection{UV-Vis Analysis}

The visual observation of the color change from light yellow to red for the gold salt/plant extract mixtures after the $1 \mathrm{~h}$ incubation (Figure 1 ) is an indication that GNPs were formed. This confirmed that the extracts were able to reduce the $\mathrm{Au}^{+3}$ ions to $\mathrm{Au}^{0}$ by the secondary metabolites/phytochemicals present in the extracts [15]. The cause of this red color in the GNPs' colloidal solution, which is not observable in the bulk material or the individual atoms, is a result of the oscillation of free conduction electrons known as Surface Plasmon Resonance (SPR) [33]. A UV-Vis spectrum with a maxima absorbance between 500 and $600 \mathrm{~nm}$ is indicative of GNPs formation [34]. Figure 2 shows the UV-Vis spectra of GNPs from Galenia-GNPs (GNPs produced from G. africana) and Hypoxis-GNPs (GNPs produced from H. hemerocallidea). Galenia-GNPs and Hypoxis-GNPs exhibited a maximum absorbance $\left(\lambda_{\max }\right)$ of $534 \pm 2 \mathrm{~nm}$ and $530 \pm 1 \mathrm{~nm}$, respectively. Several factors such as the size and the shape of the NPs, the refractive index of the medium and the inter-particle distances affect the shape and position of the GNPs' SPR in the UV-Vis spectrum [35]. In Figure 2, the band generated by Hypoxis-GNPs was sharper and more symmetrical with small absorption after $600 \mathrm{~nm}$ as opposed to Galenia-GNPs' band, which can be a sign of better uniformity in size distribution of Hypoxis-GNPs compared to Galenia-GNPs [36]. Further, the absorption tail in the Near Infrared (NIR) wavelength observed for Galenia-GNPs could be caused by the excitation of the in-plane SPR and can be a result of anisotropic GNPs [37] or the deviation from spherical geometry of the GNPs [38]. These results may indicate the presence of more effective capping agents in $H$. hemerocallidea plant extract compared to G. africana that prevented the aggregation of the GNPs and enhanced their uniformity. However, the GNPs with absorption in the NIR region have been found to be useful in several biomedical applications and in the fabrication of photonic devices such as optical sensors [39]. 


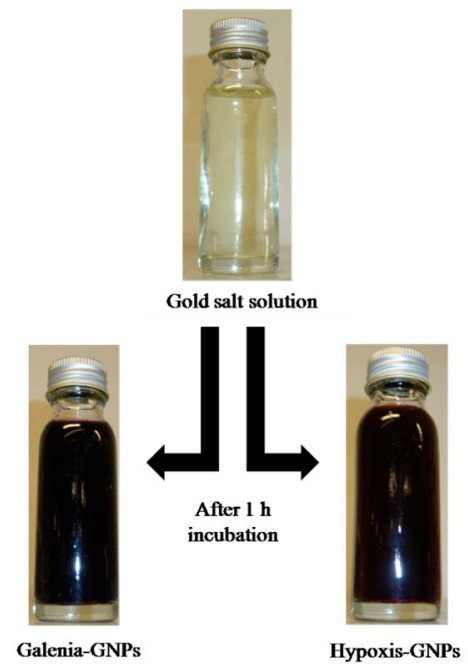

Figure 1. Digital photographs of the aqueous solutions of gold salt before the addition of the extracts, and Galenia-GNPs and Hypoxis-GNPs after $1 \mathrm{~h}$ incubation of the gold salt with the respective extracts.

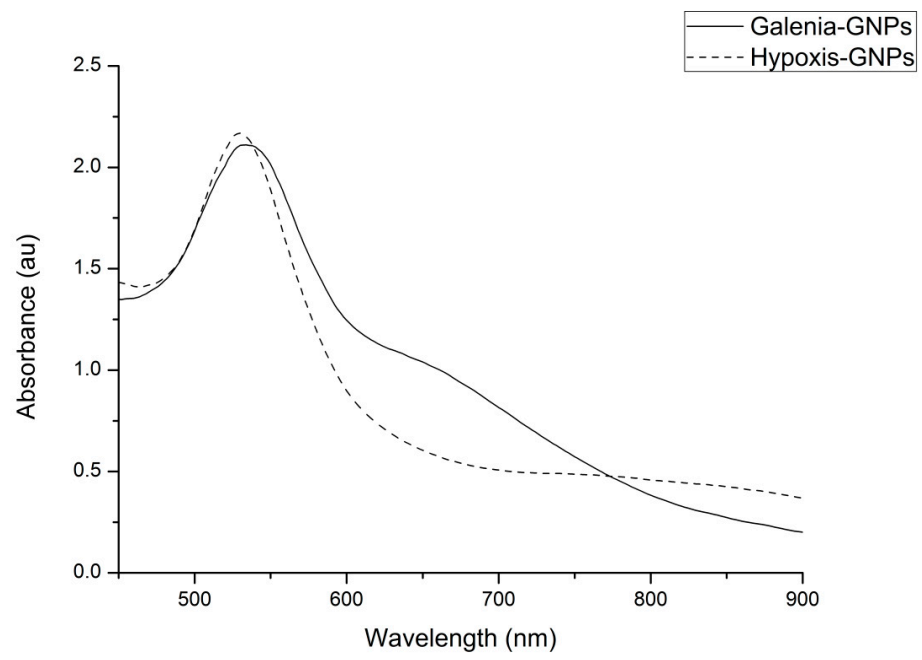

Figure 2. UV-Vis spectra of GNPs synthesized from G. africana (Galenia-GNPs) and H. hemerocallidea (Hypoxis-GNPs) plant extracts.

We also studied the kinetics of GNPs formation by examining the changes in the $\lambda_{\max }$ of the plant extract/gold salt mixtures over time. Hypoxis-GNPs started to form and show $\lambda_{\max }$ above 1 Absorbance unit (au) after $5 \mathrm{~min}$ (Figure 3A). This increase in $\lambda_{\max }$ is the result of the increasing number of GNPs as $\mathrm{Au}^{+3}$ ions are reduced to $\mathrm{Au}^{0}$ [40]. The Hypoxis-GNPs reached a maximum value after $40 \mathrm{~min}$ and thereafter remained unchanged suggesting the reaction was complete at $40 \mathrm{~min}$ (Figure 3C). On the other hand, the reaction with the G. africana plant extract started to change color and the $\lambda_{\max }$ increased above 1 au only after $20 \mathrm{~min}$ (Figure 3B) indicating the presence of lower reduction power phytochemicals in G. africana extract compared to H. hemerocallidea's. Both GNPs exhibited constant $\lambda_{\max }$ from $60 \mathrm{~min}$ (Figure 3C), which show that $1 \mathrm{~h}$ of incubation was sufficient to complete the reaction for both plant extracts. 

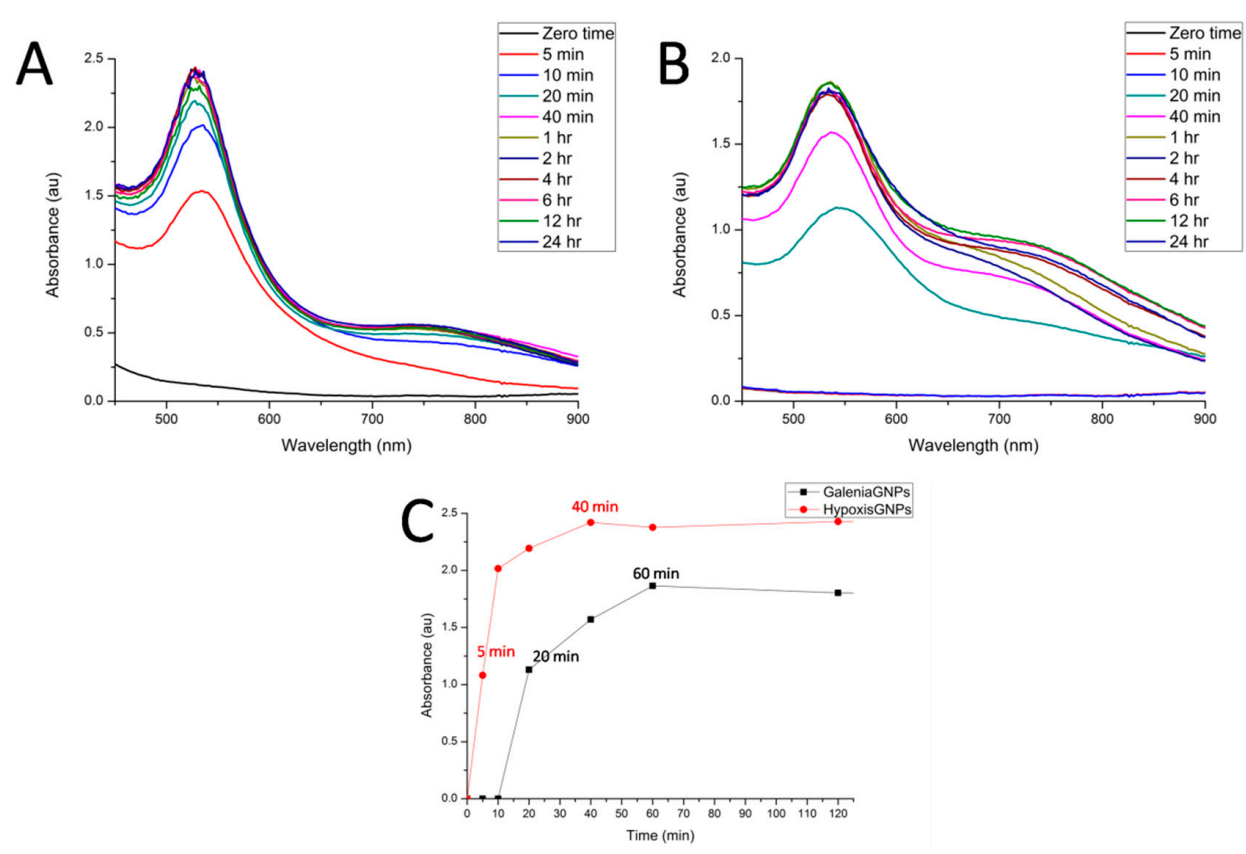

Figure 3. The UV-Vis spectra recorded as a function of time of GNPs synthesized from (A) H. hemerocallidea and (B) G. africana; (C) shows the $\lambda_{\max }$ values of the two GNPs as a function of time.

\subsection{Particle Diameter and Particle Size Distribution Analysis}

The distribution of the hydrodynamic diameters of the GNPs was measured by two different DLS-based techniques (based on size by intensity and by the number of GNPs) using the Zetasizer (Malvern Instruments Ltd., Malvern, UK). The size distribution based on intensity is depicted in Figure $4 \mathrm{~A}$, in which the scattering intensity is plotted against the logarithms of the particle diameter. Hypoxis-GNPs showed bimodal distribution, whereas Galenia-GNPs showed multimodal distribution that indicates the anisometric nature of Galenia-GNPs compared to Hypoxis-GNPs (Figure 4A). This may also explain the presence of NIR absorption peak in the UV-Vis spectrum of the Galenia-GNPs (Figure 2). In both GNPs, the peak intensity of the large particles was higher than the peak intensity of the small particles, which was expected since the particle size distribution based on the light-scattering intensity is greatly influenced by larger particles [41]. Conversely, the peaks for small particles showed higher intensity in the number-weight based size distribution (Figure 4B), with no intensity observed for larger particles. It should be taken into consideration that the error in the data obtained from number-weight size distribution is large due to its sixth power dependence on the original scattering intensity data. Yet, it can be a useful tool to compare the distribution of the two plant extracts' GNPs of small size. From Figure 4B it can be observed that the two plant extracts were able to synthesize very small GNPs (1-2 nm) in which a higher number of small size GNPs could be synthesized with G. africana extract as opposed to H. hemerocallidea as can be deduced from the intensity of the peaks. 

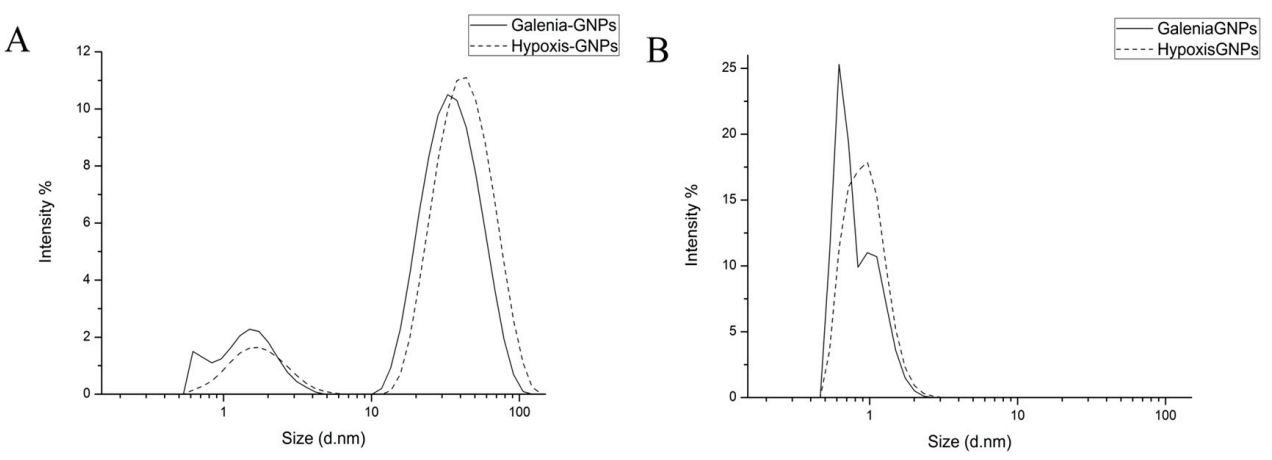

Figure 4. DLS distribution curves of GNPs' hydrodnamic diameter by (A) intensity and (B) number of GNPs.

Table 1 shows the average diameters of light-scattering intensity peaks shown in Figure 4A as well as the Z-average diameter, which is derived from the light-scattering intensity data. In agreement to the distribution curves, the Z-average diameter of the Galenia-GNPs have smaller average diameter in comparison to Hypoxis-GNPs.

Table 1. Average diameter of Galenia-GNPs and Hypoxis-GNPs obtained from DLS analysis.

\begin{tabular}{cccc}
\hline GNPs & $\begin{array}{c}\text { Small-Particle Peaks } \\
\text { Average Diameter }(\mathbf{n m})\end{array}$ & $\begin{array}{c}\text { Large-Particle Peaks } \\
\text { Average Diameter }(\mathbf{n m})\end{array}$ & $\begin{array}{c}\text { Z-Average Diameter } \\
(\mathbf{n m})\end{array}$ \\
\hline Galenia-GNPs & $1.9 \pm 1.1$ & $44 \pm 29$ & $11 \pm 1$ \\
Hypoxis-GNPs & $2.3 \pm 1.6$ & $51 \pm 34$ & $26 \pm 6$ \\
\hline
\end{tabular}

\subsection{FTIR Analysis}

The FTIR analysis was done for the plant extracts and the GNPs to identify the possible functional groups involved in the biosynthesis of GNPs. This information can aid in identifying the phytochemicals involved in the reduction of the gold salt and may also provide useful information on how to conjugate other chemical entities (e.g., small molecule drugs, peptides, nucleic acids, etc.) onto the GNPs for biomedical applications. The bio-reduction mechanism of gold ions using plants extracts continues to be elucidated, despite the increasing attention being given to the biogenic synthesis of the GNPs [42]. Several studies suggest that various phytochemicals may play a role in the synthesis of GNPs [42,43]. Generally, different chemical classes were found to influence the production of the GNPs based on the major constituent of each plant extract [32].

Figure 5 shows the FTIR spectra of both the plant extracts and the GNPs. Both GNPs showed similarities with their respective extracts, which may be due to the presence of similar compounds in both the extracts and the GNPs. Additionally, some bands of the FTIR spectra of the GNPs appeared to be shifted when compared to the FTIR spectra of the extracts. These shifts were expected and are believed to be caused by the influence of the nearby metal and possibly suggest the involvement of the corresponding functional groups in the GNPs synthesis [41]. These observed shifts are highlighted in Table 2, which also shows the possible functional groups involved in the synthesis of the GNPs from both extracts. Interestingly, some major peaks were generated in the FTIR spectra of both GNPs indicating that similar functional groups are key players in the synthesis of the GNPs. For instance, the FTIR spectra of Galenia-GNPs and Hypoxis-GNPs revealed similar broad bands at 3428 and 3420, respectively, which represents the O-H group of alcohols [12]. The intense band at $2924 \mathrm{~cm}^{-1} \mathrm{can}$ be a result of asymmetric stretching of the $\mathrm{C}-\mathrm{H}$ group [12]. Also, the peak centered at $1384 \mathrm{~cm}^{-1}$, which indicates the presence of the $-\mathrm{CH}_{3}$ group of alkanes, was also recorded in Galenia-GNPs. Galenia-GNPs also demonstrated a peak at $1329 \mathrm{~cm}^{-1}$ that corresponds to an alcoholic or phenolic $\mathrm{O}-\mathrm{H}$ group [41]. The transmittance of $\mathrm{O}-\mathrm{H}$ and $\mathrm{C}-\mathrm{O}$ bands in the FTIR spectra indicates the presence of hydroxyl and carbonyl groups on the GNPs possibly as a result of the involvement 
of flavonoids, terpenoids, phenolic compounds and/or carbohydrates in the GNPs biosynthesis (Table 2). Several studies reported the role of these hydroxyl and carbonyl containing compounds in the reduction, capping and stabilization of the GNPs [12,44]. Amino acids and proteins were also suggested to act as stabilizers of GNPs after the reduction step [13]. Yet, a quick phytochemical screening, using the Biuret and Ninhydrin tests, showed that both aqueous extracts were negative for the presence of proteins and amino acids, and hence we postulate that proteins and amino acids do not play a role in the stabilization of the GNPs in this study.

The chemical study of G. africana revealed that this plant is rich in flavonoids [21,22]. Indeed, the FTIR spectrum of G. africana aqueous extract showed a strong band at $1384 \mathrm{~cm}^{-1}$ that corresponds to the phenolic $\mathrm{O}-\mathrm{H}$ group and hence we speculate that the flavonoids of this plant are responsible for the reduction of the gold salt to produce Galenia-GNPs. Further, H. hemerocallidea is well known for producing a variety of hydroxyl-rich phytoglycosides [27]. A study by Jung et al. (2014) reported the synthesis of GNPs from several glycosides and concluded that the GNPs can be reduced as a result of the oxidation of $\mathrm{C}-6-\mathrm{OH}$ in the sugar unit into carboxylic acid [45]. The presence of the shifted band at $1267 \mathrm{~cm}^{-1}$, in the FTIR spectrum of Hypoxis-GNPs, which can be attributed to the C-O group of carboxylic acids, may be a result of the oxidation of the aforementioned oxidation site (Table 2). One of the major secondary metabolites of H. hemerocallidea is Hypoxoside, which is a phytoglycoside compound containing the same oxidation site reported by Jung et al. (2014). Hence, we also speculate that Hypoxoside may play a major role in the synthesis of the GNPs. Clearly, these major compounds should be isolated and tested for the synthesis of the GNPs in order to identify, with certainty, the actual functional groups responsible for the synthesis of the GNPs from each plant. This investigation is ongoing.
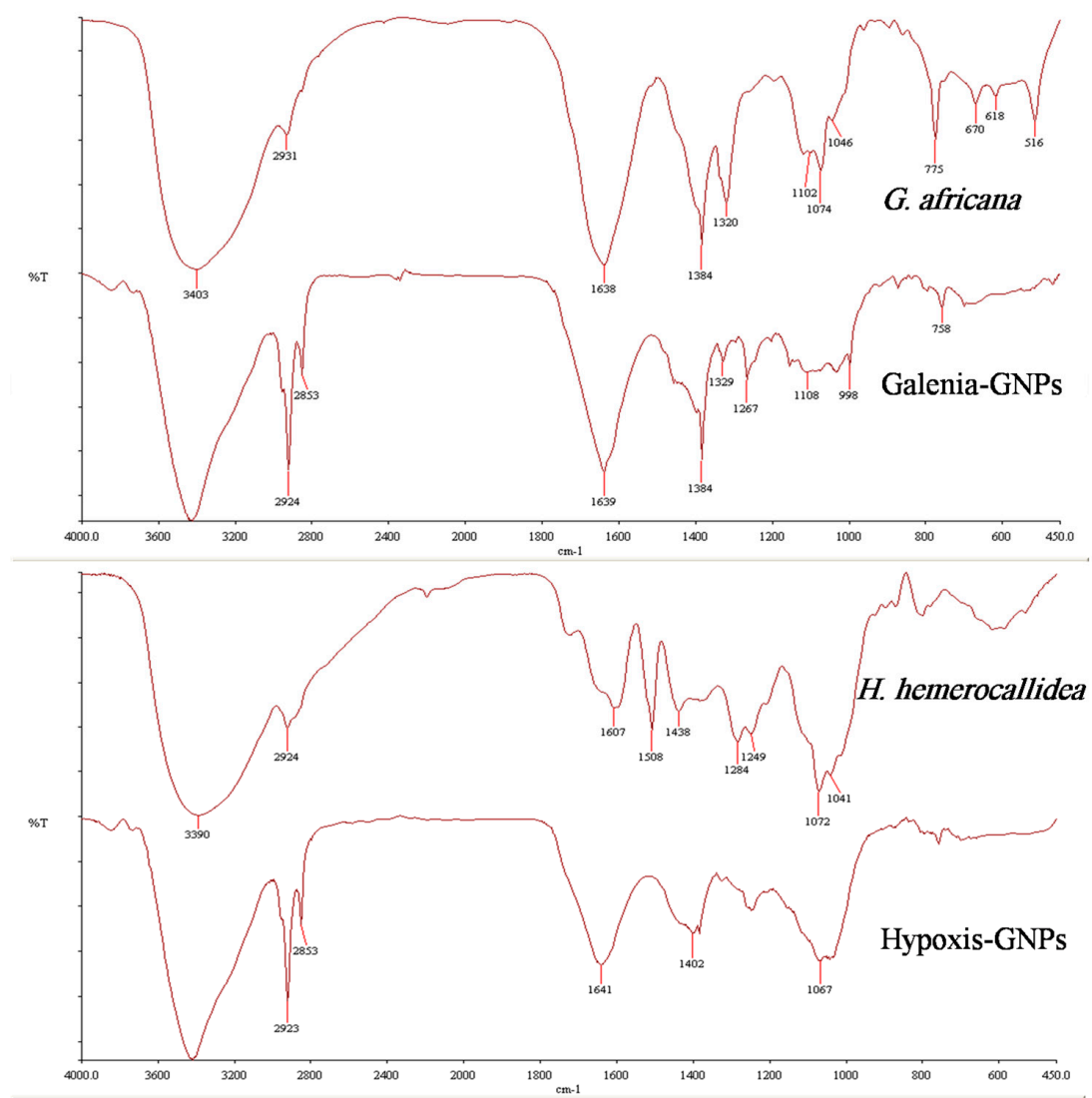

Figure 5. FTIR spectra of $H$. hemerocallidea and G. africana and their respective GNPs. 
Table 2. Shifts of the FTIR spectra bands $\left(\mathrm{cm}^{-1}\right)$ of the major peaks of H. hemerocallidea and G. africana aqueous extracts and their respective GNPs.

\begin{tabular}{|c|c|c|c|c|c|c|c|}
\hline \multicolumn{4}{|c|}{ G. africana } & \multicolumn{4}{|c|}{ H. hemerocallidea } \\
\hline $\begin{array}{l}\text { Aqueous } \\
\text { Extract }\end{array}$ & Galenia-GNPs & Shift Value * & $\begin{array}{l}\text { Possible Functional } \\
\text { Groups }\end{array}$ & $\begin{array}{c}\text { Aqueous } \\
\text { Extract }\end{array}$ & Hypoxis-GNPs & Shift Value * & $\begin{array}{c}\text { Possible Functional } \\
\text { Groups }\end{array}$ \\
\hline 3403 & 3428 & -25 & $\begin{array}{c}\mathrm{O}-\mathrm{H} \\
\text { Alcohols }\end{array}$ & 3390 & 3420 & -30 & $\begin{array}{c}\mathrm{O}-\mathrm{H} \\
\text { Alcohols }\end{array}$ \\
\hline 2931 & 2924 & +7 & $\begin{array}{c}\text { C-H } \\
\text { Alkanes }\end{array}$ & 2924 & 2923 & +1 & $\begin{array}{c}\text { C-H } \\
\text { Alkanes }\end{array}$ \\
\hline 1384 & 1384 & 0 & $\begin{array}{c}-\mathrm{CH}_{3} \\
\text { Alkanes }\end{array}$ & 1438 & 1402 & +36 & $\begin{array}{c}\mathrm{C}=\mathrm{C} \\
\text { Aromatics }\end{array}$ \\
\hline 1320 & 1329 & -9 & $\begin{array}{c}\text { O-H } \\
\text { Alcohols, Phenols }\end{array}$ & 1249 & 1267 & -18 & $\begin{array}{c}\mathrm{C}-\mathrm{O} \\
\text { Aromatic esters, } \\
\text { Ethers, Carboxylic } \\
\text { acids }\end{array}$ \\
\hline 775 & 758 & +17 & $\begin{array}{c}\mathrm{C}-\mathrm{Cl} \\
\text { Alkanes } \\
\text { C-H } \\
\text { Benzenes }\end{array}$ & 1072 & 1067 & -5 & $\mathrm{C}-\mathrm{O}-\mathrm{C}$ \\
\hline
\end{tabular}

* The shift values were calculated by subtracting the peak transmittence of GNPs from the peak transmittance of the extract.

\subsection{HRTEM and EDX Analysis}

The HRTEM analysis of the GNPs was done to study their morphologies, crystalline nature and their particle size distribution. Interestingly, the HRTEM images show predominance of spherical GNPs from the two plant extracts (Figure 6). Due to the presence of numerous phytochemicals in the extracts that are capable of reducing the gold salt, it is common that plant phytochemicals produce GNPs with a mixture of geometrical shapes [32]. It is suggested that the presence of strong interaction forces between the capping bio-molecules and the surfaces of GNPs could keep the nascent GNPs from sintering, resulting in small sized spherical GNPs [33]. Therefore, the synthesis of spherical shapes in this study may imply that the capping agents, present in H. hemerocallidea and G. africana, exhibit strong interaction with the newly grown GNPs and prevent them from developing into other shapes. Yet, some deviations from the spherical shapes were observed in the HRTEM images of the two GNPs (Figure 7). These deviations, which were more common in Galenia-GNPs, may explain the absorbance peak beyond $600 \mathrm{~nm}$ in the UV-Vis spectra of Galenia-GNPs in Figure 2.

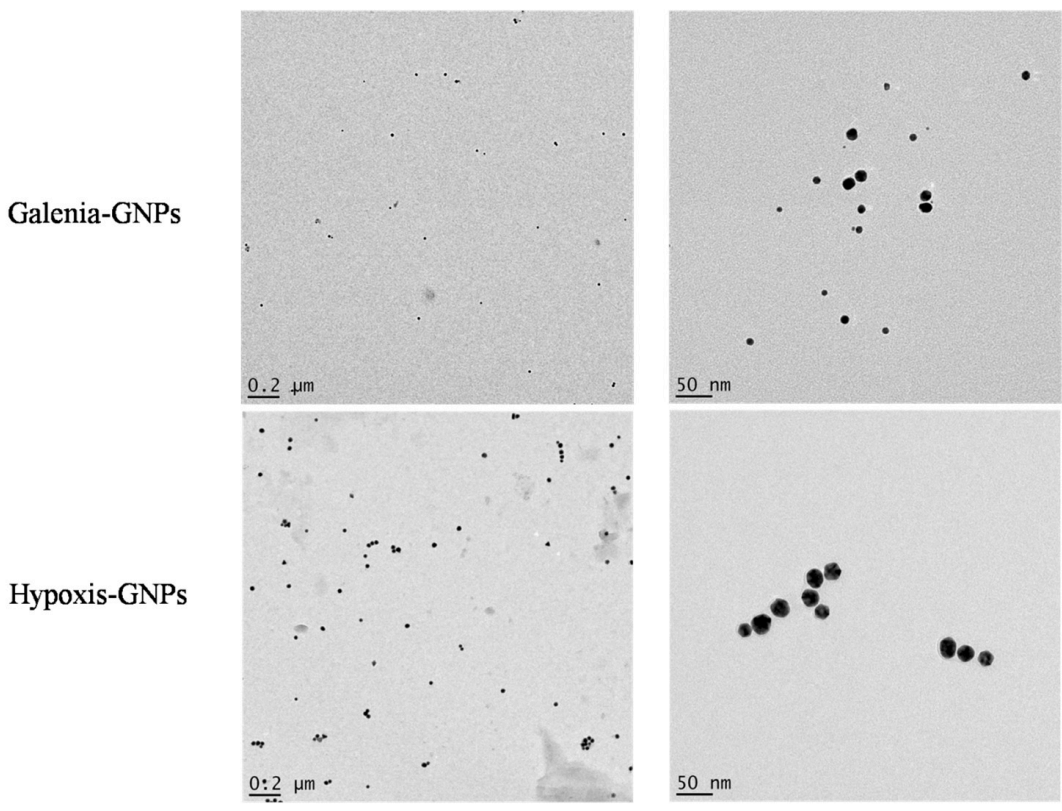

Figure 6. HRTEM images of Galenia-GNPs and Hypoxis-GNPs. 

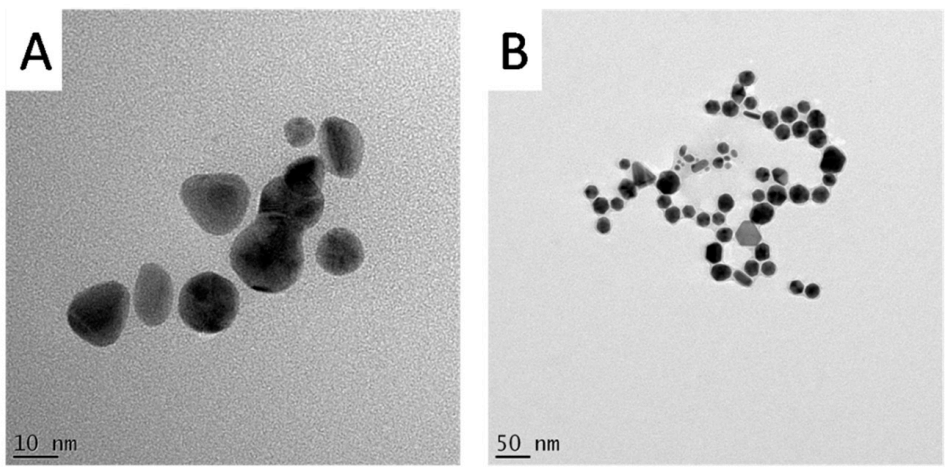

Figure 7. HRTEM images showing spherical deviations observed in (A) Galenia-GNPs and (B) Hypoxis-GNPs.

The HRTEM analysis also revealed the crystalline nature of the GNPs. Figure 8A,C show the lattice fringes of the two GNPs. The shortest lattice distances were 0.234 and $0.227 \mathrm{~nm}$ for Hypoxis-GNPs and Galenia-GNPs, respectively (Figure 8A,C). These values correspond approximately to the interplanar spacing between (111) planes of gold [46]. The crystalline nature of the GNPs was also confirmed by the selected area electron diffraction (SAED). The bright rings were found to correspond to the (111), (200), (220), (311) and (222) planes of the gold (Figure 8B,D).

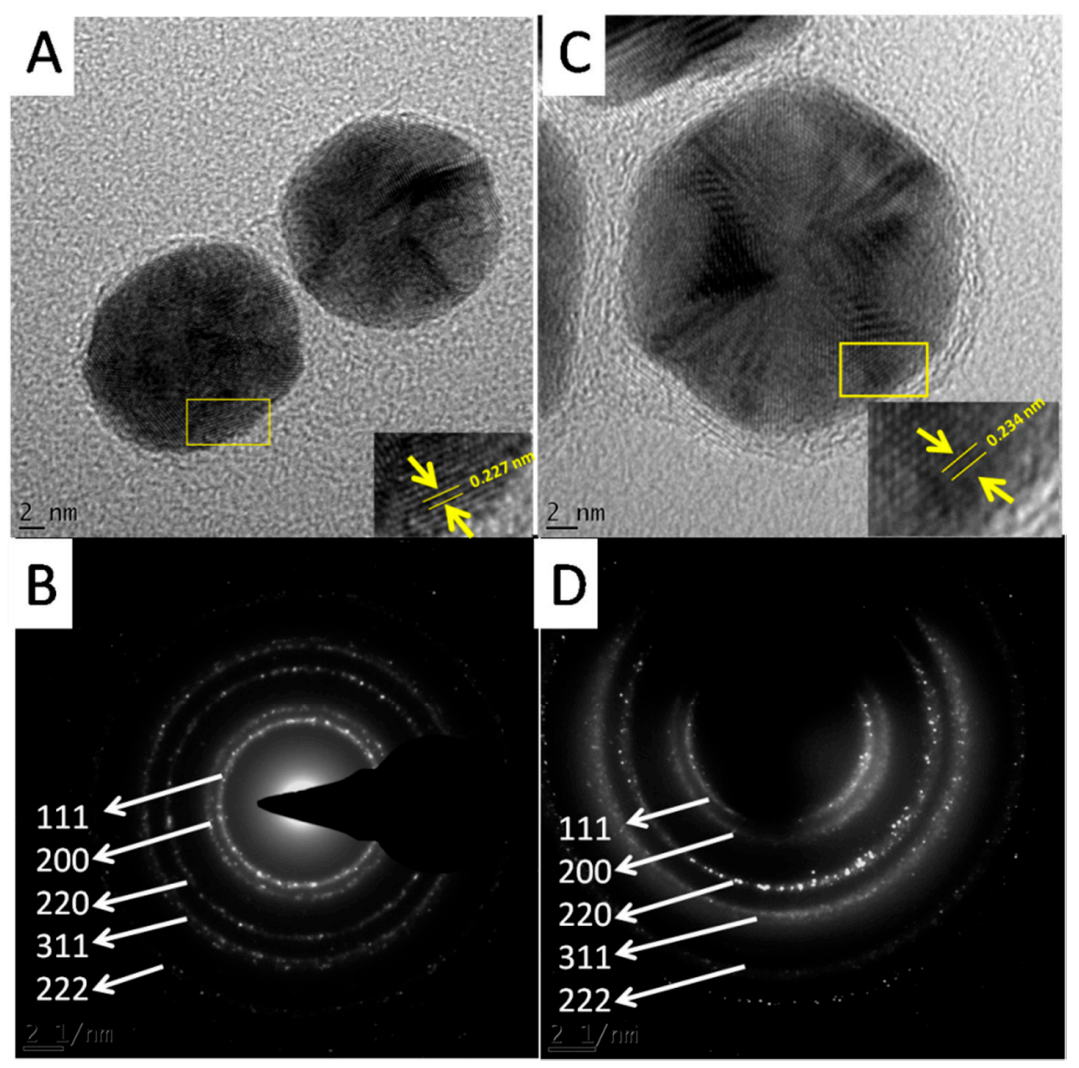

Figure 8. HRTEM images showing fringe lattics observed in (A) Galenia-GNPs and (C) Hypoxis-GNPs, and SAED pattern of (B) Galenia-GNPs and (D) Hypoxis-GNPs.

The particle size distributions obtained from the HRTEM images were similar to the DLS data (Figure 9). The particle size range of Galenia-GNPs was between 2 and $16 \mathrm{~nm}$ with the largest number of the particles being between 8 and $10 \mathrm{~nm}$ in diameter (Figure 9A). On the other hand, the particle size of Hypoxis-GNPs ranged from 10 to $45 \mathrm{~nm}$ with the majority of the NPs being between 25 and 
$30 \mathrm{~nm}$ in diameter (Figure 9B). Also, the average particle size of Galenia-GNPs (9 $\pm 2 \mathrm{~nm}$ ) was smaller than those of Hypoxis-GNPs $(27 \pm 6 \mathrm{~nm})$ as obtained by HRTEM analysis. It must be noted that the hydrodynamic particle size data obtained from the DLS analysis is usually larger than the particle size determined by HRTEM [12]. Indeed, the average size of Galenia-GNPs obtained by HRTEM was smaller than the average size determined by Zetasizer. Conversely, the average size of Hypoxis-GNPs as determined by HRTEM was slightly larger than the size obtained using the Zetasizer. Yet, it must be taken into consideration that only a few NPs are shown in each frame of the HRTEM images, so any shape and size distributions determinations of the GNPs using HRTEM images will not be completely statistically reliable [41].
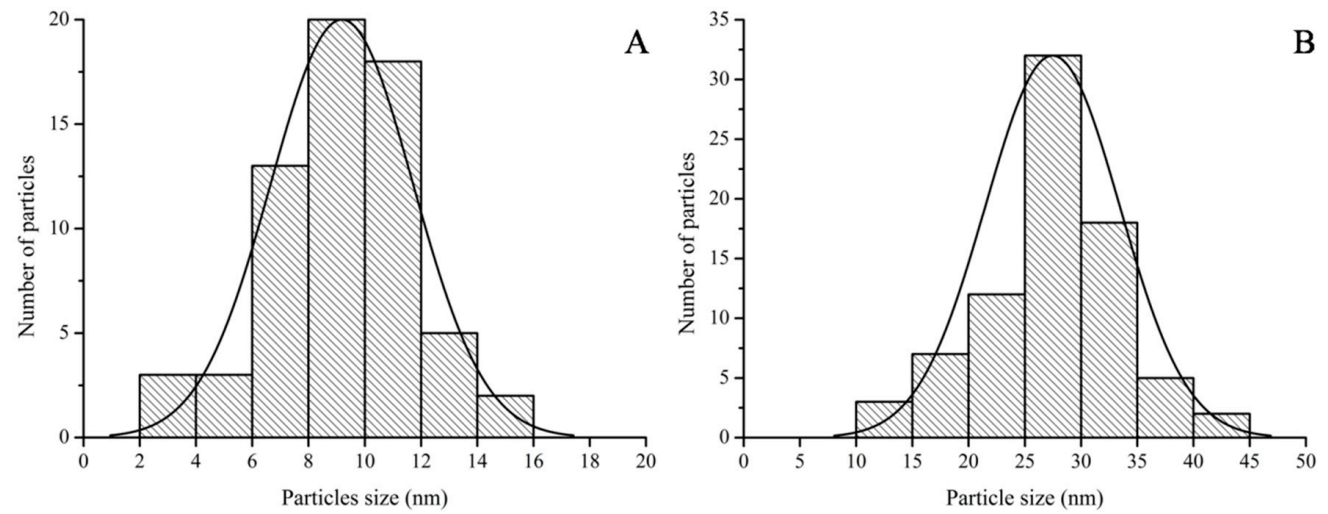

Figure 9. Particle size distributions of (A) Galenia-GNPs and (B) Hypoxis-GNPs as obtained from the HRTEM images.

The concentration of GNPs in this study was determined using their UV-Vis data as reported [47]. Using multipole scattering theory, Haiss and co-workers (2007) showed that the optical properties of the spherical GNPs are dependent on the particle size. As a result, the authors showed that the molar concentration and particle size of the GNPs could be deduced from their UV-Vis spectra. Hence, it was useful to measure the difference in the particle size data obtained using the three methods applied in this study, i.e., Zetasizer, HRTEM and UV-Vis spectra (Table 3). The results in Table 3 confirmed that three techniques showed that Galenia-GNPs were smaller in size when compared to Hypoxis-GNPs. The difference in size between Galenia-GNPs and Hypoxis-GNPs as determined by the Zetasizer and HRTEM was $15 \mathrm{~nm}$ and $18 \mathrm{~nm}$, respectively, while the size determined using the UV-Vis spectra was $8 \mathrm{~nm}$.

Table 3. Average particle size of Galenia-GNPs and Hypoxis-GNPs as obtained from the Zetasizer, HRTEM and UV-Vis spectra.

\begin{tabular}{cccc}
\hline \multirow{2}{*}{ Type of GNPs } & \multicolumn{3}{c}{ Average Size (nm) } \\
\cline { 2 - 4 } & Zetasizer & HRTEM & UV-Vis \\
\hline Galenia-GNPs & $11 \pm 1$ & $9 \pm 2$ & 10 \\
Hypoxis-GNPs & $26 \pm 6$ & $27 \pm 6$ & 18 \\
Difference in size * $^{*}+15$ & +18 & +8 \\
\hline
\end{tabular}

* Difference was calculated as follow: (average size of Hypoxis-GNPs) - (average size of Galenia-GNPs).

The presence of the elemental gold was confirmed in the graphs obtained from the EDX spectroscopy analysis of the GNPs. The EDX data showed adsorption of gold peaks at around 2.3, 9.7 and $11.3 \mathrm{keV}$ (Figure 10). These values are in agreement with a previous study [48]. The presence of carbon, copper and silicon peaks in the samples is attributed to the HRTEM grid and/or the detector window [49]. On the other hand, traces of the phytochemicals of the extracts present around the GNPs or in the medium may have caused the presence of oxygen peaks [13]. 

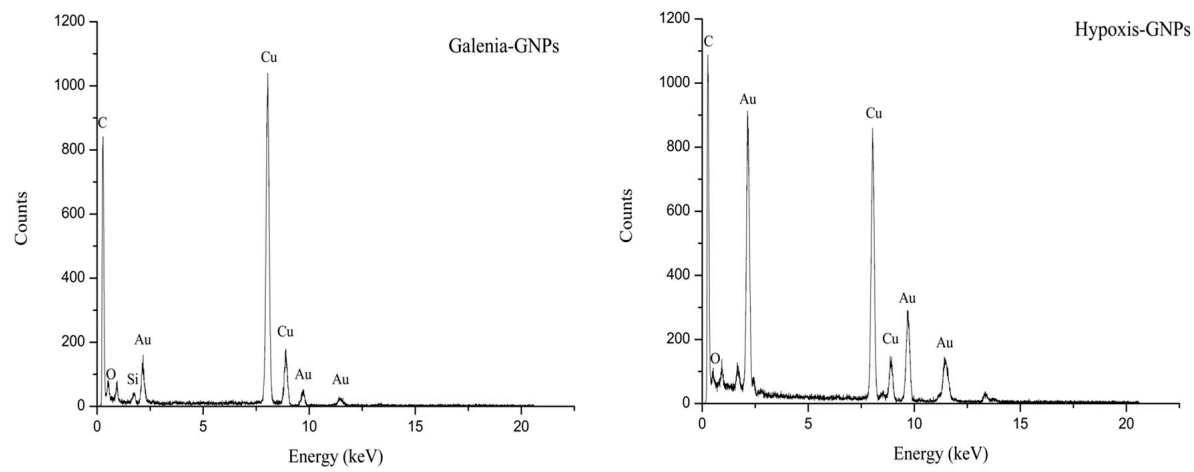

Figure 10. EDX spectra of Galenia-GNPs and Hypoxis-GNPs.

\subsection{Thermal Study}

The TGA was done in order to determine the percentage of the organic matter (phytochemicals involved in the synthesis) present in the GNPs. The weight loss of $5 \mathrm{mg}$ of the GNPs and the extracts was measured between 20 and $800{ }^{\circ} \mathrm{C}$ (Figure 11). Table 4 summarizes the weight loss percentage of the extracts and the GNPs at different temperatures. Unlike the extracts, both GNPs did not show weight loss at $100{ }^{\circ} \mathrm{C}$. Any weight loss at this temperature is believed to be a result of the loss of evaporation of adsorbed water [50]. It is expected that most organic compounds and functional groups will be completely burned off at $400{ }^{\circ} \mathrm{C}[51,52]$. Table 4 shows that Hypoxis-GNPs and Galenia-GNPs, respectively, only lost $2.5 \%$ and $3.4 \%$ of their weight at $400{ }^{\circ} \mathrm{C}$. Both of the extracts showed nearly $50 \%$ weight loss at the same temperature. The thermal decomposition of resistant aromatic compounds and biogenic salts is expected to occur at temperatures beyond $400{ }^{\circ} \mathrm{C}$ [50]. Thus, the lower weight loss in the case of G. africana may be as a result of the presence of higher content of these heat resistant compounds. At $800{ }^{\circ} \mathrm{C}$ Galenia-GNPs showed more weight loss (4\%) when compared to Hypoxis-GNPs. It should be noted that the amount of the G. africana extract used in the synthesis of Galenia-GNPs was twice the amount of H. hemerocallidea extract used to synthesize the Hypoxis-GNPs (as mentioned in Section 3) and it was therefore expected that the weight loss value of Galenia-GNPs would be higher compared to Hypoxis-GNPs.
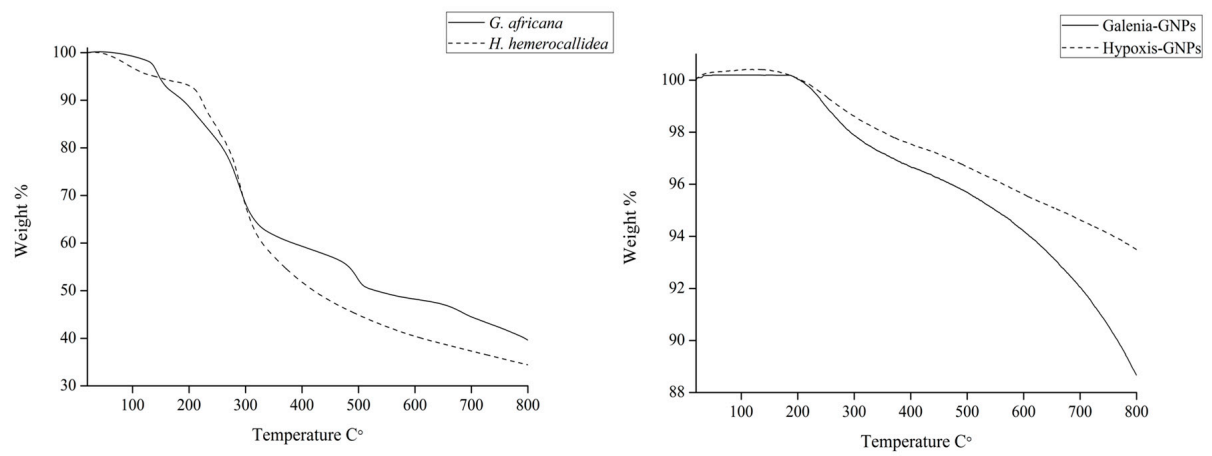

Figure 11. TGA data for H. hemerocallidea and G. africana and their respective GNPs.

Table 4. Weight (expressed as percentage) of H. hemerocallidea and G. africana extracts and their respective GNPs at different temperatures as obtained from TGA.

\begin{tabular}{cccc}
\hline Sample & Weight $\boldsymbol{\%}$ at $\mathbf{1 0 0}{ }^{\circ} \mathbf{C}$ & Weight $\%$ at $\mathbf{4 0 0}{ }^{\circ} \mathbf{C}$ & Weight $\%$ at $\mathbf{8 0 0}{ }^{\circ} \mathbf{C}$ \\
\hline Hypoxis-GNPs & $100 \%$ & $97.5 \%$ & $91.8 \%$ \\
Galenia-GNPs & $100 \%$ & $96.6 \%$ & $87.7 \%$ \\
H. hemerocallidea extract & $96.8 \%$ & $52 \%$ & $34 \%$ \\
G. africana extract & $99.2 \%$ & $60 \%$ & $39 \%$ \\
\hline
\end{tabular}




\subsection{Stability of the GNPS}

To understand the stability of the GNPs, the zeta potential values, measured immediately after the synthesis, were obtained using the Zetasizer. Hypoxis-GNPs and Galenia-GNPs demonstrated negative zeta potential values of -22 and -20 , respectively. These negative values can estimate the long-term stability of the GNPs in a solution, as they can provide enough repulsion forces between the particles and prevent their agglomeration [53].

If these GNPs are to be considered for biomedical applications, they must maintain their stability in different buffer solutions (e.g., Sodium Chloride $(\mathrm{NaCl})$, cysteine and Bovine Serum Albumin (BSA)). The stability of the GNPs was measured after incubation with the aforementioned buffer solutions as well as the growth media used in the biological assays in this study (Dulbecco's Modified Eagle's Medium (DMEM) supplemented with 10\% Fetal Bovine Serum (FBS) and Nutrient broth). The GNPs were incubated at $37^{\circ} \mathrm{C}$ with DMEM and Nutrient broth in order to determine the effect of the media on the stability of the GNPs under experimental conditions. A minimal change in the UV-Vis spectra of the GNPs is an indication of the GNPs stability. When the GNPs lose stability they may precipitate, which can be observed by the significant red shifts and broadening of the UV-Vis bands [54]. After measuring the UV-Vis of the two GNPs incubated with different buffers and the biological media over a $24 \mathrm{~h}$ period, it was observed that these GNPs were generally stable in most of the buffer conditions tested with no changes in the UV-Vis bands (Figure 12). One exception was the effect of $0.5 \%$ cysteine on Galenia-GNPs, which caused the UV-Vis bands to become broader at all the time-points. Nonetheless, Galenia-GNPs showed excellent stability in DMEM that usually contains cysteine and other amino acids but at lower concentrations.

Hypoxis-GNPs
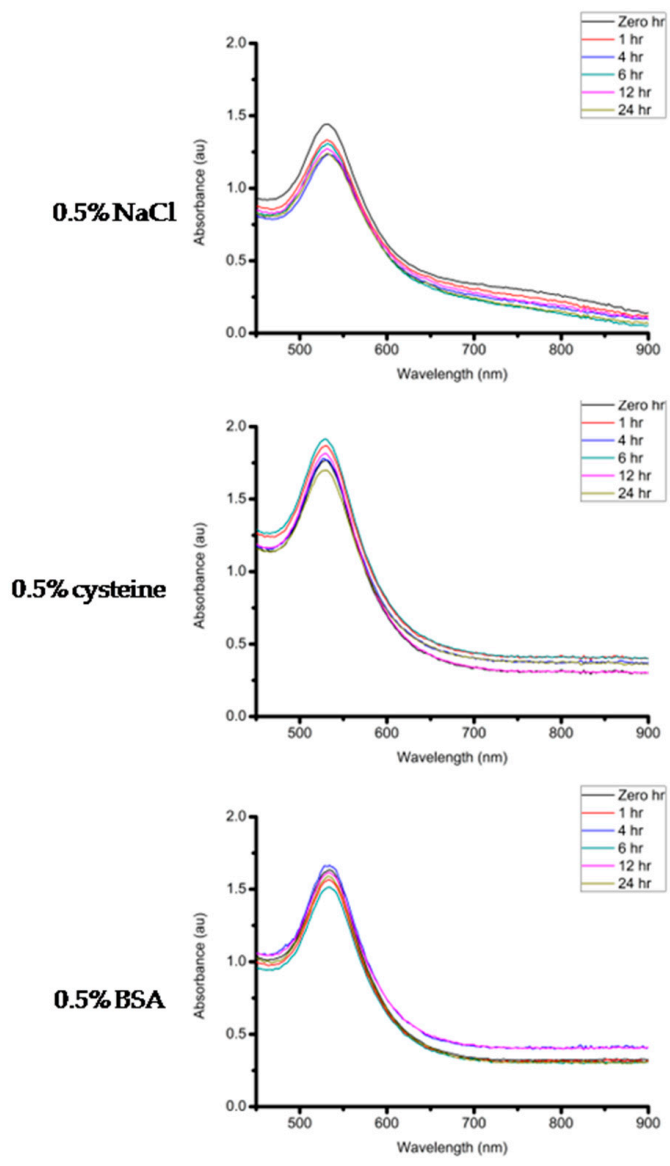

Galenia-GNPs
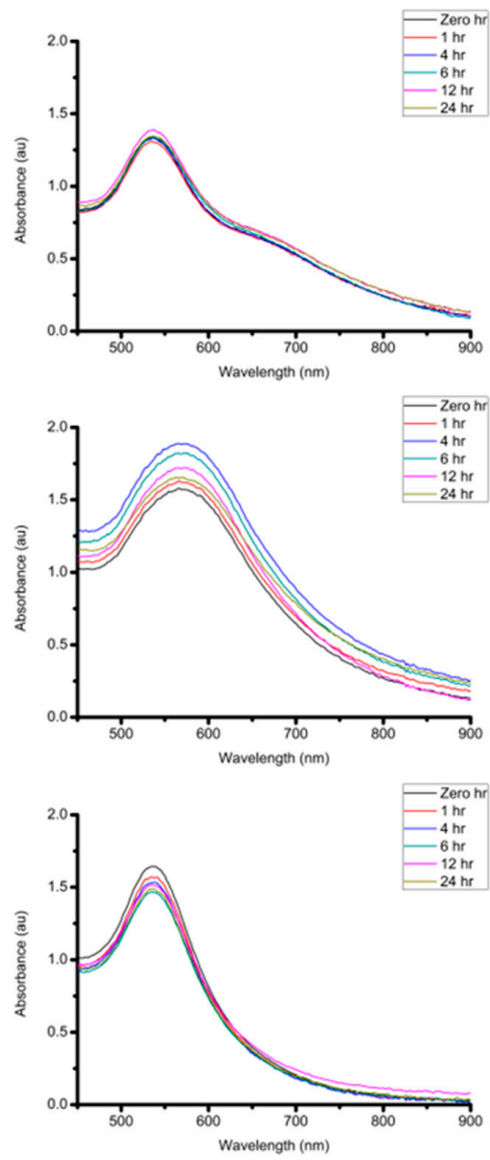

Figure 12. Cont. 

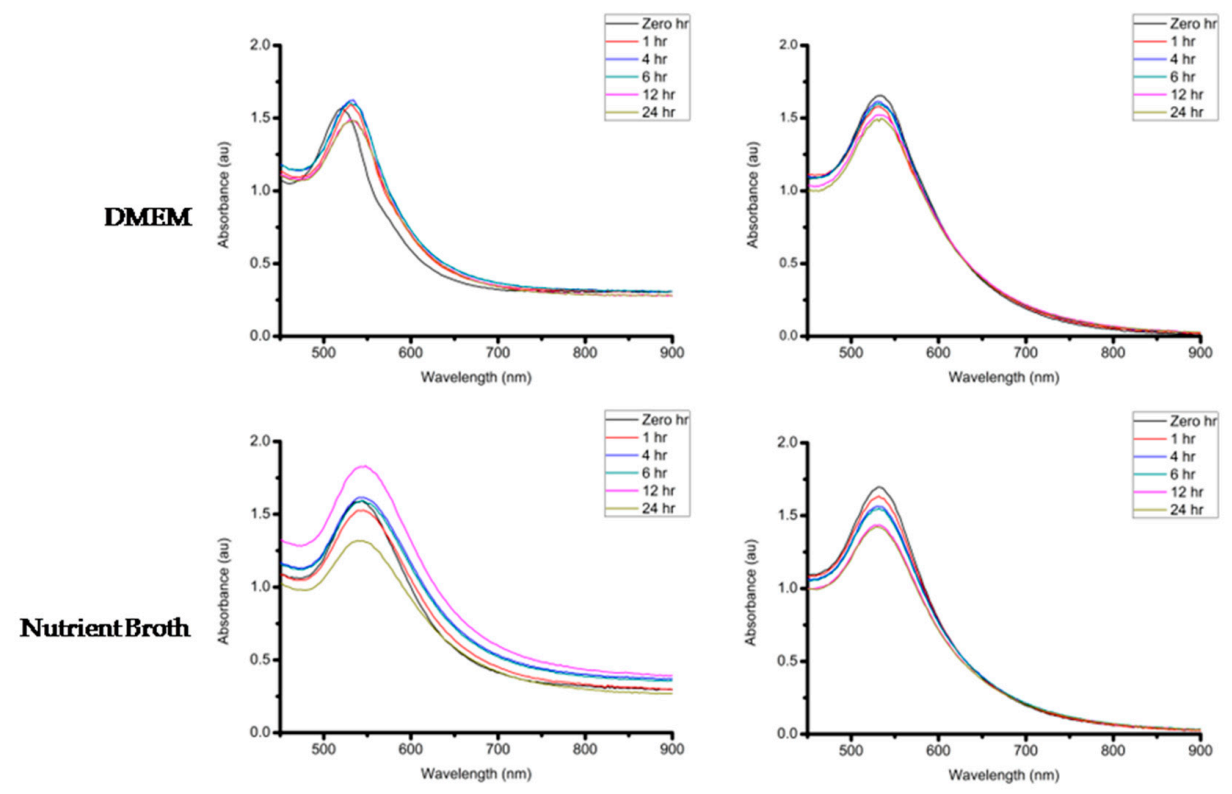

Figure 12. UV-Vis spectra of the GNPs taken over a 24-h period in buffers containing $0.5 \% \mathrm{NaCl}$, $0.5 \%$ cysteine and $0.5 \%$ BSA, Nutrient broth and in DMEM supplemented with 10\% FBS.

\subsection{Antibacterial Effects and Toxicity of the GNPS}

Generally, the antibacterial effect of different plant extracts is well documented and recognized. However, the antibacterial effect of the biogenic metal NPs produced from such plant extracts still remains largely unexplored and can prove useful in the search for new antibacterial agents [12]. For this reason, the antibacterial activities of Hypoxis-GNPs, Galenia-GNPs along with the tested plant extracts were investigated. The Alamar blue assay was used to measure the bacterial growth after treatment. Resazurin (Alamar blue dye) undergoes colorimetric change in response to cellular metabolic reduction to give the highly fluorescent compound resorufin that can be quantified by measuring its fluorescence [55]. The Minimum Inhibitory Concentration (MIC) in this study was defined as the lowest concentration of the tested samples that significantly $(p<0.05)$ inhibits the growth of the tested bacterial strains as compared to the negative control value. The antibacterial evaluation was done against a panel of gram-positive and gram-negative bacterial strains that are known to cause wound infections.

The MIC values for the GNPs and the plant extracts are summarized in Table 5. The antibiotic Ampicillin was included as a positive control. The antibacterial effect of citrate-capped GNPs was also tested. Hypoxis-GNPs demonstrated significant antibacterial activity against the tested bacterial strains when compared to Galenia-GNPs. Interestingly, the MIC value of the Hypoxis-GNPs ( $32 \mathrm{nM}$ ) was the same for the bacterial strains. However, the viability of the bacteria at this MIC value varied between the different bacterial strains. For instance, P. aeruginosa was the most susceptible by Hypoxis-GNPs and showed the lowest viability with $10 \pm 1 \%$ compared to $16 \pm 1 \%, 20 \pm 1 \%$ and $43 \pm 5 \%$ for $E$. coli, Staphylococcus epidermidis and S. aureus, respectively. Galenia-GNPs only showed an antibacterial effect on $P$. aeruginosa with a MIC value of $32 \mathrm{nM}$ and viability of $35 \pm 5 \%$. Further, none of the aqueous plant extracts induced any growth inhibition in this study. However, Ncube et al. (2012) reported that the $H$. hemerocallidea aqueous extract have an MIC value of $12.5 \mathrm{mg} / \mathrm{mL}$ against $S$. aureus and E. coli, which is significantly higher than the highest concentration tested in this study [30]. Katerere and Eloff (2008) also reported that the acetone corm extract of this plant had a low MIC value of $0.31 \mathrm{mg} / \mathrm{mL}$ against $S$. aureus [56]. This difference is likely to be attributed to the difference in the chemical nature of phytochemicals present in the acetone and water extracts. The citrate-capped GNPs failed to induce similar antibacterial activity as observed with the biogenic GNPs. Also, the MIC 
values obtained for Ampicillin were within the ranges reported in previous studies [57-59]. The MIC for Ampicillin was significantly higher for P. aeruginosa $(2 \mathrm{mg} / \mathrm{mL})$ compared to the other bacterial strains tested. The increased resistance of P. aeruginosa to Ampicillin is possibly due to changes in the penicillin-binding proteins, membrane impermeability and the production of beta-lactamases [60].

Table 5. The MIC values of the GNPs, the aqueous extracts and Ampicillin on the tested bacterial strains. The viability recorded at each MIC of the GNPs are written in brackets.

\begin{tabular}{ccccc}
\hline \multirow{2}{*}{ Sample Tested } & \multicolumn{4}{c}{ Bacterial Strains } \\
\cline { 2 - 5 } & S. aureus & E. coli & S. epidermidis & P. aeruginosa \\
\hline Hypoxis-GNPs $(\mathrm{nM})$ & $32(43 \pm 5 \%)^{*}$ & $32(16 \pm 1 \%)^{* * *}$ & $32(20 \pm 1 \%)^{* * *}$ & $32(10 \pm 1 \%)^{* * *}$ \\
Galenia-GNPs $(\mathrm{nM})$ & $>32$ & $>32$ & $>32$ & $32(35 \pm 5 \%)^{* *}$ \\
Citrate GNPs $(\mathrm{nM})$ & $>32$ & $>32$ & $>32$ & $>32$ \\
H. hemerocallidea extract $(\mathrm{mg} / \mathrm{mL})$ & $>0.48$ & $>0.48$ & $>0.48$ & $>0.48$ \\
G. africana extract $(\mathrm{mg} / \mathrm{mL})$ & $>0.48$ & $>0.48$ & $>0.48$ & $>0.48$ \\
Ampicillin $(\mathrm{mg} / \mathrm{mL})$ & 0.004 & 0.002 & 0.0005 & 2.0 \\
\hline
\end{tabular}

*** Statistical significance $(p<0.001)$ compared to negative control, ${ }^{* *}$ Statistical significance $(p<0.01)$ compared to negative control, * Statistical significance $(p<0.05)$ compared to negative control.

It is thought that the smaller size of the GNPs compared to the size of the bacterium enables the GNPs to exert bacterium cell death by adhering to its cell wall [61]. The GNPs can then penetrate the cell wall of the bacterium and induce death by affecting respiratory mechanisms and cell division by binding to protein- or phosphorus-containing compounds, such as DNA [62]. It is believed that the variation in activity against the bacterial strains is dictated by the nature of the bacterial cell wall. The cell wall of the gram-positive bacterial strains, for example, has a thicker peptidoglycan layer compared to the cell wall of the gram-negative bacteria [63]. As a result, GNPs can penetrate the cell wall of the gram-negative bacteria and exert their antibacterial action more easily than in gram-positive bacteria [64]. Accordingly, the variation in the viability of the bacterial strains after treatment with the MIC value of Hypoxis-GNPs could be attributed to the nature of the cell wall composition. In fact, growth inhibition caused by the Hypoxis-GNPs was more significant in the two gram-negative bacterial strains (E. coli and P. aeruginosa).

Furthermore, the results show that the aqueous plant extracts lacked any bacterial activity at the highest concentration tested in this study in contrast to the biogenic GNPs. It is, however, possible that a higher concentration of the extracts can be active against these bacterial strains as demonstrated previously [30]. The lower antibacterial activity of the extracts compared to the GNPs may be due to the fact that either the bacteria are adopting resistance mechanisms against the free phytochemicals or there is some synergistic activity between the GNPs and the capping phytochemicals [65]. The higher antibacterial activity of the biogenic GNPs may also be associated with the increase in the concentration of the active phytochemicals capping the GNPs. Consequently, when bacteria are exposed to the GNPs an augmented antibacterial effect is obtained. It is also possible that the GNPs have more targeting effect or higher affinity towards the bacterial cells in comparison to the free phytochemicals. The fact that the non-phytochemical capped GNPs (Citrate NPs) was not as active as Hypoxis- or Galenia-GNPs further supports the role of the phytochemicals in inhibiting the bacterial growth. In addition, it is known that the antibacterial activity of the NPs is inversely proportional on their particle size [66], yet the bigger size Hypoxis-GNPs were more active against the bacteria than the smaller particle size Galenia-GNPs. Hence, it could be speculated that the properties of the phytochemicals capping the NPs are an important factor in determining the antibacterial activity regardless of the size of the GNPs.

In view of the fact that biogenic GNPs such as Hypoxis-GNPs and Galenia-GNPs can potentially be applied in wound dressings to protect the exposed tissue against bacterial infections, we also investigated the potential toxicity of these GNPs to the human fibroblast cells. The toxicity of the GNPs towards the KMST- 6 cell line therefore was established using in vitro cell culture testing. Figure 13 shows that there was no significant reduction in the viability of KMST-6 cells after a $24 \mathrm{~h}$ treatment with different concentrations (up to $32 \mathrm{nM}$ ) of the GNPs, which is equivalent to the MIC values obtained for 
the GNPs against some of the bacterial strains. This preliminary data suggests that these GNPs are safe for therapeutic use.

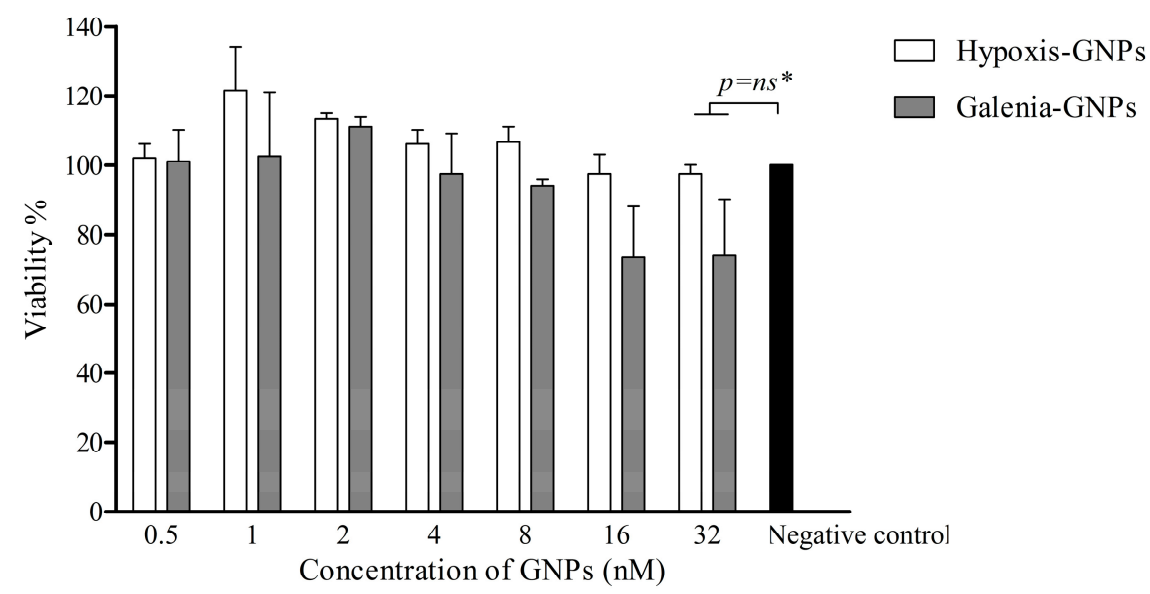

Figure 13. The effect of the GNPs on the cell viability of KMST-6 as determined by the MTT assay.

* No statistically significant difference $(p>0.05)$ compared to the negative control.

\section{Materials and Methods}

\subsection{Materials}

The aqueous extract of $H$. hemerocallidea was purchased from Afriplex (Cape Town, South Africa). Polystyrene 96-well microtitre plates were obtained from Greiner bio-one GmbH (Frickenhausen, Germany). Ampicillin, 3-[4,5-dimethylthiazol-2-yl]-2,5-diphenyl tetrazolium bromide (MTT) and gold salt (sodium tetrachloroaurate (III) dihydrate) were purchased from Sigma-Aldrich (Cape Town, South Africa). N-Acetyl-L-cystein and Alanin were purchased from Boehringer Mannheim $\mathrm{GmbH}$ (Mannheim, Germany). DMEM, penstrep (penicillin-streptomycin) and Phosphate buffered saline (PBS) were purchased from Lonza (Cape Town, South Africa). BSA was procured from Miles Laboratories (Pittsburgh, PA, USA). FBS was bought from Thermo Scientific (Ansfrere, South Africa). Nutrient broth and Miller Hinton agar were purchased from Biolab (supplied by Merck, Modderfontein, South Africa). Alamar blue dye was obtained from Invitrogen Corporation (San Diego, CA, USA). $\mathrm{NaCl}$, Sodium Hydroxide $(\mathrm{NaOH})$ and Ninhydrin reagent were brought from Merck (Cape Town, South Africa). Citrate-capped GNPs (14 nm) were obtained from DST/Mintek Nanotechnology Innovation Centre (Gauteng, South Africa).

\subsection{Preparation of G. africana Aqueous Extract}

G. africana was collected during the month of May 2015 from the Western Cape Province, South Africa. The plant was identified by Dr. Chris N. Cupido, the co-author of this paper, and a specimen was deposited in Kirstenbosch National Botanical Garden (Cape Town, South Africa) under accession number 1468255/NBG. The fresh aerial parts of G. africana were dried in the shade. To obtain the aqueous extract, $50.0 \mathrm{~mL}$ of boiled distilled water were added to $5.0 \mathrm{~g}$ of the dried plant powder. Afterwards, the plant decoction was centrifuged for $2 \mathrm{~h}$ at $3750 \mathrm{rpm}$ using an Allegra ${ }^{\circledR} \mathrm{X}-12 \mathrm{R}$ centrifuge (Beckman Coulter, Cape Town, South Africa). The supernatant was then filtered through $0.45 \mu \mathrm{m}$ filters and freeze-dried using FreeZone 2.5 L freeze-dryer (Labconco, Kansas City, MO, USA).

\subsection{Biogenic Synthesis of the GNPs and Their Characterization}

The H. hemerocallidea and G. africana plant extracts were first screened for the production of GNPs in 96-well microtitre plates using the method reported in a previous study [32]. In short, $250 \mu \mathrm{L}$ of $1.0 \mathrm{mM}$ sodium tetrachloroaurate (III) dihydrate were mixed with $50.0 \mu \mathrm{L}$ of each plant extract in 
a 96-well microtitre plate (the concentrations of the extracts varied from 8.0 to $0.125 \mathrm{mg} / 300 \mu \mathrm{L}$ ). The plate was incubated for $1 \mathrm{~h}$ at $70{ }^{\circ} \mathrm{C}$ with shaking at $40.0 \mathrm{rpm}$. The production of the GNPs was monitored by measuring the UV-Vis spectra $(450-900 \mathrm{~nm})$ using a POLARstar Omega microtitre plate reader (BMG Labtech, Cape Town, South Africa). For further evaluations of the GNPs, the volume of the gold salt and plant extracts mixtures was up-scaled after determining the optimum concentrations of the plant extracts that produce desirable GNPs $(0.5 \mathrm{mg} / 300 \mu \mathrm{L}$ for G. africana and $0.25 \mathrm{mg} / 300 \mu \mathrm{L}$ for H. hemerocallidea). The GNPs were then centrifuged and the pellets were washed trice with distilled water and ultimately re-suspended in distilled water.

\subsection{DLS Analysis}

The zeta potential and hydrodynamic size values of the freshly synthesized GNPs were measured using a Zetasizer (Malvern Instruments Ltd., Malvern, UK) at $25^{\circ} \mathrm{C}$ and a $90^{\circ}$ angle. Zetasizer software version 7.11 was used to analyze the data.

\subsection{FTIR Spectroscopy}

The FTIR analysis was done using PerkinElmer spectrum one FTIR spectrophotometer (Waltham, MA, USA) according to the method reported previously [7]. The freeze-dried GNPs and the extracts were added to $\mathrm{KBr}$ powder and pressed into a round disk. A pure $\mathrm{KBr}$ round disk was used for background correction.

\subsection{HRTEM and EDX Analysis}

One drop of the GNPs solution was added onto a carbon coated copper grid. The grids were allowed to dry for a few minutes under a Xenon lamp. The HRTEM images were obtained using FEI Tecnai $G^{2} 20$ field-emission gun (FEG) HRTEM operated in bright field mode at an accelerating voltage of $200 \mathrm{kV}$. The elemental composition of the GNPs was identified using EDX liquid nitrogen cooled Lithium doped Silicon detector.

\subsection{Image Processing}

The image analysis software Image 1.50b version 1.8.0_60 (http:/ /imagej.nih.gov/ij) was used to analyze the HRTEM images.

\subsection{TGA}

The TGA was done using PerkinElmer TGA 4000 (Waltham, MA, USA). The freeze-dried GNPs $(5.0 \mathrm{mg})$ or plant extracts $(5.0 \mathrm{mg})$ were heated from 20 to $800{ }^{\circ} \mathrm{C}$ in nitrogen atmosphere (flow rate was $20.0 \mathrm{~mL} / \mathrm{min}$ ) [67]. The temperature was increased at a rate of $10^{\circ} \mathrm{C} / \mathrm{min}$.

\subsection{Stability Evaluation of the GNPS}

To measure the effect of different aqueous buffer solutions (e.g., $0.5 \% \mathrm{NaCl}, 0.5 \%$ cysteine and $0.5 \% \mathrm{BSA}$ ) on the stability of the biogenic GNPs, $100 \mu \mathrm{L}$ of the GNPs solutions were mixed with $100 \mu \mathrm{L}$ of the buffer solutions in a 96-well microtitre plate. The stability of the GNPs was also evaluated in DMEM (supplemented with 10\% FBS) and Nutrient broth. The stability of the GNPs was monitored by measuring the UV-Vis spectrum (between 450 and $900 \mathrm{~nm}$ ) of the samples at 1, 4, 6, 12 and $24 \mathrm{~h}$ after mixing the GNPs with the buffer solutions or the media.

\subsection{Phytochemical Screening}

\subsubsection{Test for Proteins (Biuret Test)}

The phytochemical assays were done as described previously with minor modifications [68]. To test the aqueous extracts for the presence of proteins, a few drops of $5.0 \% \mathrm{NaOH}$ and a few drops 
of $1.0 \% \mathrm{Cu}\left(\mathrm{SO}_{4}\right)_{2}$ were added to $2.0 \mathrm{~mL}$ of each aqueous extract. BSA was used as a positive control. A violet color change indicated the presence of proteins.

\subsubsection{Test for Amino Acids (Ninhydrin Test)}

Few drops of Ninhydrin reagent were added to $2.0 \mathrm{~mL}$ of the aqueous extracts. The mixtures were heated in water bath for $10 \mathrm{~min}$. Alanin was used as a positive control. The formation of purple color indicated the presence of amino acids.

\subsection{Cytotoxicity Evaluation of the GNPs}

The toxicity of the GNPs was tested on the non-cancerous human fibroblast cell line (KMST-6). The cells were maintained in DMEM containing $10 \%$ FBS and $1 \%$ penstrep in a $37^{\circ} \mathrm{C}$ humidified incubator with $5 \% \mathrm{CO}_{2}$ saturation. The viability of the KMST-6 cells was evaluated using the MTT assay as described by Mmola and co-workers with some modifications [65]. The cells were seeded in a 96-well microtitre plates at a density of $2.0 \times 10^{4}$ cells $/ 100 \mu \mathrm{L} /$ well. The plates were incubated at $37^{\circ} \mathrm{C}$ in a humidified $\mathrm{CO}_{2}$ incubator. After $24 \mathrm{~h}$, the culture medium was replaced with fresh medium containing the GNPs at increasing concentrations of 0.5 to $32 \mathrm{nM}$. The concentrations of the GNPs were calculated from their UV-Vis spectra as described previously [47]. As a positive control, cells were treated with $50.0 \mu \mathrm{M} \mathrm{C}_{2}$-Ceramide, which is a known inducer of apoptotic cell death [69]. Untreated cells were used as a negative control. All treatments were done in triplicate. After $24 \mathrm{~h}$, the GNPs were removed and the wells were washed with PBS to ensure complete removal of GNPs. Thereafter, $100 \mu \mathrm{L}$ of MTT reagent (prepared from $5.0 \mathrm{mg} / \mathrm{mL}$ stock solution and diluted with DMEM medium using a dilution factor of $1: 10$ ) were added to each well. The plates were incubated again at $37^{\circ} \mathrm{C}$ for $4 \mathrm{~h}$. The MTT reagent was then removed and replaced with $100 \mu \mathrm{L}$ alkaline DMSO to dissolve the purple formazan crystals as recommended by Wang and colleagues [70]. After a 15 min incubation period at $37^{\circ} \mathrm{C}$, the absorbance of the samples was measured at $540 \mathrm{~nm}$ using the microtitre plate reader. The absorbance at $630 \mathrm{~nm}$ was used as a reference wavelength. The percentage of cell viability was calculated using the following equation:

$$
\% \text { cell viability }=\frac{\text { sample absorbance }- \text { cell free sample blank }}{\text { negative control absorbance }}
$$

\subsection{Antibacterial Evaluation of the GNPs}

Table 6 lists the bacterial strains selected for testing the antibacterial activity of the GNPs in this study. The Alamar blue assay was used to evaluate the inhibition of bacterial growth by both the GNPs and the plant extracts. The test was done according to the manufacturer's instructions. The bacterial strains were first cultured and maintained on Miller Hinton agar plates. Single colonies were then inoculated into Nutrient broth and incubated at $37{ }^{\circ} \mathrm{C}$ with shaking for overnight. The number of bacterial cells was determined and adjusted to $0.5 \mathrm{McF}$ arland using $\mathrm{OD}_{450}$ to give final cell concentration of $1-2 \times 10^{8} \mathrm{CFU} / \mathrm{mL}$ [71]. The cell cultures were further diluted in order to give a final concentration of $5.0 \times 10^{5} \mathrm{CFU} / \mathrm{mL}$ as recommended by the European committee for Antimicrobial Susceptibility Testing (EUCAST). To determine the MIC values of the tested samples, $50.0 \mu \mathrm{L}$ of the bacterial broth were mixed, in a 96 microtitre plate, with $50.0 \mu \mathrm{L}$ of the GNPs (the concentrations of the GNPs varied between 0.5 and $32 \mathrm{nM}$ ) or $50.0 \mu \mathrm{L}$ of the plant extracts (the concentrations of the plant extracts varied between 30.0 and $480 \mu \mathrm{g} / \mathrm{mL}$ ). Ampicillin was used as a positive control. Negative controls were also prepared by mixing $50.0 \mu \mathrm{L}$ of the bacterial culture with $50.0 \mu \mathrm{L}$ of Nutrient broth. The plates were incubated at $37^{\circ} \mathrm{C}$ for $24 \mathrm{~h}$, after which $10.0 \mu \mathrm{L}$ of the Alamar blue dye were added to each well. The plates were further incubated for a $3 \mathrm{~h}$ and then the fluorescence of resorufin was measured using a microtitre plate reader at $544 \mathrm{~nm}$ (excitation wavelength) and $590 \mathrm{~nm}$ (emission wavelength). To evaluate whether the GNPs and plant extracts interfere with the Alamar blue assay, a sample control was also prepared by mixing $50.0 \mu \mathrm{L}$ of the GNPs and the plant extracts (all the 
different concentrations were tested) with $50.0 \mu \mathrm{L}$ of nutrient broth. The fluorescence of the sample control was subtracted from the sample fluorescence as illustrated in the equation below, which was used to calculate the percentage bacterial growth.

$$
\% \text { bacterial growth }=\frac{(\text { sample fluorescence }- \text { sample control })-\text { cell free sample blank }}{\text { negative control fluorescence }} \times 100
$$

Table 6. List of bacterial strains used in the antibacterial assay.

\begin{tabular}{ccc}
\hline Bacterial Strains & ATCC Number & Gram Reaction \\
\hline E. coli & 25,922 & Gram-negative \\
P. aeruginosa & 27,853 & Gram-negative \\
S. aureus & 29,213 & Gram-positive \\
S. epidermidis & 12,228 & Gram-positive \\
\hline
\end{tabular}

\subsection{Statistical Analysis}

The data presented are means \pm SD obtained from at least three independent experiments. Differences between the means were considered to be significant if $p<0.05$ according to Prism's two-way ANOVA.

\section{Conclusions}

The study demonstrated an effective and easy methodology for the green synthesis of GNPs from two South African plant extracts, G. africana and H. hemerocallidea. To the best of our knowledge, this is the first report on GNPs synthesis from these two plants. The GNPs were characterized using different spectroscopic and microscopic techniques such as UV-Vis, DLS analysis, HRTEM, EDX, TGA and FTIR. G. africana and H. hemerocallidea produced spherical GNPs with an average particle size of $11 \pm 1$ and $26 \pm 6 \mathrm{~nm}$, respectively, as determined by DLS analysis. The FTIR data suggested that the flavonoids of G. africana and the glycosides contents of $H$. hemerocallidea might be responsible for the biogenic synthesis of the GNPs. In vitro stability investigation showed that both GNPs, in particular Hypoxis-GNPs, are stable when incubated with different biological buffers and the culture media. Hypoxis-GNPs showed a higher antibacterial effect compared to Galenia-GNPs against the bacterial strains tested in this study. Both GNPs were found to be non-toxic against a non-cancerous human fibroblast cell line suggesting that it may be safe to use these GNPs in wound dressings for the prevention of wound infections. However, more cytotoxic assays should be carried out to fully determine their toxicity. Additionally, a wider panel of bacterial strains that are known to cause skin infections should be investigated.

Acknowledgments: The authors would like to thank the South African National Research Foundation (NRF) and the DST/Mintek Nanotechnology Innovation Centre (NIC) for funding this research.

Author Contributions: Abdulrahman M. Elbagory, Mervin Meyer and Ahmed A. Hussein conceived and designed the experiments and analyzed the data; Christopher N. Cupido collected and identified G. africana; Abdulrahman M. Elbagory performed the experiments and drafted the paper; Mervin Meyer and Ahmed A. Hussein coordinated writing the paper to which all co-authors contributed.

Conflicts of Interest: The authors report no conflicts of interest in this work.

\section{References}

1. Ahmed, S.; Annu; Ikram, S.; Yudha, S. Biosynthesis of gold nanoparticles: A green approach. J. Photochem. Photobiol. B Biol. 2016, 161, 141-153. [CrossRef] [PubMed]

2. Sekhon, B.S. Nanotechnology in agri-food production: An overview. Nanotechnol. Sci. Appl. 2014, 7, 31-53. [CrossRef] [PubMed] 
3. Sýkora, D.; Kašička, V.; Mikšík, I.; Řezanka, P.; Záruba, K.; Matějka, P.; Král, V. Application of gold nanoparticles in separation sciences. J. Sep. Sci. 2010, 33, 372-387. [CrossRef] [PubMed]

4. Santhoshkumar, J.; Rajeshkumar, S.; Venkat Kumar, S. Phyto-assisted synthesis, characterization and applications of gold nanoparticles-A review. Biochem. Biophys. Rep. 2017, 11, 46-57. [CrossRef] [PubMed]

5. Qiu, P.; Yang, M.; Qu, X.; Huai, Y.; Zhu, Y.; Mao, C. Tuning photothermal properties of gold nanodendrites for in vivo cancer therapy within a wide near infrared range by simply controlling their degree of branching. Biomaterials 2016, 104, 138-144. [CrossRef] [PubMed]

6. Santra, T.S.; Tseng, F.-G.; Barik, T.K. Green biosynthesis of gold nanoparticles and biomedical applications. Am. J. Nano Res. Appl. 2014, 2, 5-12. [CrossRef]

7. Khan, M.; Khan, M.; Adil, S.F.; Tahir, N.M.; Tremel, W.; Alkhathlan, H.Z.; Al-Warthan, A.; Siddiqui, M.R.H. Green synthesis of silver nanoparticles mediated by Pulicaria glutinosa extract. Int. J. Nanomed. 2013, 8, 1507-1516. [CrossRef]

8. Wang, F.; Nimmo, S.L.; Cao, B.; Mao, C. Oxide formation on biological nanostructures via a structure-directing agent: Towards an understanding of precise structural transcription. Chem. Sci. 2012, 3, 2639-2645. [CrossRef] [PubMed]

9. Wang, F.; Li, D.; Mao, C. Genetically Modifiable Flagella as Templates for Silica Fibers: From Hybrid Nanotubes to 1D Periodic Nanohole Arrays. Adv. Funct. Mater. 2008, 18, 4007-4013. [CrossRef]

10. Kitching, M.; Ramani, M.; Marsili, E. Fungal biosynthesis of gold nanoparticles: Mechanism and scale up. Microb. Biotechnol. 2015, 8, 904-917. [CrossRef] [PubMed]

11. He, S.; Guo, Z.; Zhang, Y.; Zhang, S.; Wang, J.; Gu, N. Biosynthesis of gold nanoparticles using the bacteria Rhodopseudomonas capsulata. Mater. Lett. 2007, 61, 3984-3987. [CrossRef]

12. Dorosti, N.; Jamshidi, F. Plant-mediated gold nanoparticles by Dracocephalum kotschyi as anticholinesterase agent: Synthesis, characterization, and evaluation of anticancer and antibacterial activity. J. Appl. Biomed. 2016, 14, 235-245. [CrossRef]

13. Balashanmugam, P.; Durai, P.; Balakumaran, M.D.; Kalaichelvan, P.T. Phytosynthesized gold nanoparticles from C. roxburghii DC. leaf and their toxic effects on normal and cancer cell lines. J. Photochem. Photobiol. B Biol. 2016, 165, 163-173. [CrossRef] [PubMed]

14. Rajan, A.; Rajan, A.R.; Philip, D. Elettaria cardamomum seed mediated rapid synthesis of gold nanoparticles and its biological activities. OpenNano 2017, 2, 1-8. [CrossRef]

15. Yuan, C.G.; Huo, C.; Yu, S.; Gui, B. Biosynthesis of gold nanoparticles using Capsicum annuum var. grossum pulp extract and its catalytic activity. Phys. E Low-Dimens. Syst. Nanostruct. 2017, 85, 19-26. [CrossRef]

16. Song, J.-Y.; Byun, T.-G.; Kim, B.-S. Synthesis of Magnetic Nanoparticles Using Magnolia kobus Leaf Extract. Process Biochem. J. 2012, 27, 157-160. [CrossRef]

17. Siddiqi, K.S.; Husen, A. Recent advances in plant-mediated engineered gold nanoparticles and their application in biological system. J. Trace Elem. Med. Biol. 2017, 40, 10-23. [CrossRef] [PubMed]

18. Sreelakshmi, C.; Datta, K.K.R.; Yadav, J.S.; Reddy, B.V.S. Honey derivatized Au and Ag nanoparticles and evaluation of its antimicrobial activity. J. Nanosci. Nanotechnol. 2011, 11, 6995-7000. [CrossRef] [PubMed]

19. Ayaz Ahmed, K.B.; Subramanian, S.; Sivasubramanian, A.; Veerappan, G.; Veerappan, A. Preparation of gold nanoparticles using Salicornia brachiata plant extract and evaluation of catalytic and antibacterial activity. Spectrochim. Acta Part A Mol. Biomol. Spectrosc. 2014, 130, 54-58. [CrossRef] [PubMed]

20. MubarakAli, D.; Thajuddin, N.; Jeganathan, K.; Gunasekaran, M. Plant extract mediated synthesis of silver and gold nanoparticles and its antibacterial activity against clinically isolated pathogens. Colloids Surf. B Biointerfaces 2011, 85, 360-365. [CrossRef] [PubMed]

21. Vries, F.A.; El Bitar, H.; Green, I.R.; Klaasen, J.A.; Bodo, B.; Johnson, Q.; Mabusela, W.T. An antifungal active extract from the aerial parts of Galenia africana. In Proceedings of the 11th Napreca Symposium Book of Proceedings, Antananarivo, Madagascar, 9-12 August 2005; pp. 123-131.

22. Mativandlela, S.P.N.; Muthivhi, T.; Kikuchi, H.; Oshima, Y.; Hamilton, C.; Hussein, A.A.; van der Walt, M.L.; Houghton, P.J.; Lall, N. Antimycobacterial flavonoids from the leaf extract of Galenia africana. J. Nat. Prod. 2009, 72, 2169-2171. [CrossRef] [PubMed]

23. Hutchings, A.; Scott, A.; Lewis, G.; Cunningham, A. Zulu Medicinal Plants: An Inventory; Illustrate; Hutchings, A., Ed.; University of Natal Press: Pietermaritzburg, South Africa, 1996; ISBN 0869808931, 9780869808931. 
24. Bryant, A.T. Zulu Medicine and Medicine-Men. In Annals of the Natal Museum; Warren, E., Ed.; Adlard \& Son and West Newman: London, UK, 1916; Volume 2, pp. 1-103.

25. Drewes, S.E.; Elliot, E.; Khan, F.; Dhlamini, J.T.B.; Gcumisa, M.S.S. Hypoxis hemerocallidea-Not merely a cure for benign prostate hyperplasia. J. Ethnopharmacol. 2008, 119, 593-598. [CrossRef] [PubMed]

26. Lall, N.; Kishore, N. Are plants used for skin care in South Africa fully explored? J. Ethnopharmacol. 2014, 153, 61-84. [CrossRef] [PubMed]

27. Bassey, K.; Viljoen, A.; Combrinck, S.; Choi, Y.H. New phytochemicals from the corms of medicinally important South African Hypoxis species. Phytochem. Lett. 2015, 10, lxix-1xxv. [CrossRef]

28. Su, X.; Liu, X.; Wang, S.; Li, B.; Pan, T.; Liu, D.; Wang, F.; Diao, Y.; Li, K. Wound-healing promoting effect of total tannins from Entada phaseoloides (L.) Merr. in rats. Burns 2017, 43, 830-838. [CrossRef] [PubMed]

29. McGaw, L.J.; Lall, N.; Meyer, J.J.M.; Eloff, J.N. The potential of South African plants against Mycobacterium infections. J. Ethnopharmacol. 2008, 119, 482-500. [CrossRef] [PubMed]

30. Ncube, B.; Finnie, J.F.; Van Staden, J. In vitro antimicrobial synergism within plant extract combinations from three South African medicinal bulbs. J. Ethnopharmacol. 2012, 139, 81-89. [CrossRef] [PubMed]

31. Virkutyte, J.; Varma, R.S. Green synthesis of metal nanoparticles: Biodegradable polymers and enzymes in stabilization and surface functionalization. Chem. Sci. 2011, 2, 837-846. [CrossRef]

32. Elbagory, A.M.; Cupido, C.N.; Meyer, M.; Hussein, A.A. Large Scale Screening of Southern African Plant Extracts for the Green Synthesis of Gold Nanoparticles Using Microtitre-Plate Method. Molecules 2016, 21, 1498. [CrossRef] [PubMed]

33. Sujitha, M.V.; Kannan, S. Green synthesis of gold nanoparticles using Citrus fruits (Citrus limon, Citrus reticulata and Citrus sinensis) aqueous extract and its characterization. Spectrochim. Acta Part A Mol. Biomol. Spectrosc. 2013, 102, 15-23. [CrossRef] [PubMed]

34. Rastogi, L.; Arunachalam, J. Microwave-Assisted Green Synthesis of Small Gold Nanoparticles Using Aqueous Garlic (Allium sativum) Extract: Their Application as Antibiotic Carriers. Int. J. Green Nanotechnol. 2012, 4, 163-173. [CrossRef]

35. Guo, L.; Jackman, J.A.; Yang, H.H.; Chen, P.; Cho, N.J.; Kim, D.H. Strategies for enhancing the sensitivity of plasmonic nanosensors. Nano Today 2015, 10, 213-239. [CrossRef]

36. Saifuddin, N.; Wong, C.W.; Nur Yasumira, A.A. Rapid Biosynthesis of Silver Nanoparticles Using Culture Supernatant of Bacteria with Microwave Irradiation. E-J. Chem. 2009, 6, 61-70. [CrossRef]

37. Narayanan, K.B.; Sakthivel, N. Coriander leaf mediated biosynthesis of gold nanoparticles. Mater. Lett. 2008, 62, 4588-4590. [CrossRef]

38. Shipway, A.N.; Lahav, M.; Gabai, R.; Willner, I. Investigations into the electrostatically induced aggregation of Au nanoparticles. Langmuir 2000, 16, 8789-8795. [CrossRef]

39. Smitha, S.L.; Philip, D.; Gopchandran, K.G. Green synthesis of gold nanoparticles using Cinnamomum zeylanicum leaf broth. Spectrochim. Acta Part A Mol. Biomol. Spectrosc. 2009, 74, 735-739. [CrossRef] [PubMed]

40. Mishra, A.; Tripathy, S.K.; Yun, S.I. Fungus mediated synthesis of gold nanoparticles and their conjugation with genomic DNA isolated from Escherichia coli and Staphylococcus aureus. Process Biochem. 2012, 47, 701-711. [CrossRef]

41. Elia, P.; Zach, R.; Hazan, S.; Kolusheva, S.; Porat, Z.; Zeiri, Y. Green synthesis of gold nanoparticles using plant extracts as reducing agents. Int. J. Nanomed. 2014, 9, 4007-4021. [CrossRef]

42. Singh, P.; Kim, Y.J.; Zhang, D.; Yang, D.C. Biological Synthesis of Nanoparticles from Plants and Microorganisms. Trends Biotechnol. 2016, 34, 588-599. [CrossRef] [PubMed]

43. Baker, S.; Rakshith, D.; Kavitha, K.S.; Santosh, P.; Kavitha, H.U.; Rao, Y.; Satish, S. Plants: Emerging as nanofactories towards facile route in synthesis of nanoparticles. BioImpacts 2013, 3, 111-117. [CrossRef] [PubMed]

44. Ajitha, B.; Ashok Kumar Reddy, Y.; Sreedhara Reddy, P. Green synthesis and characterization of silver nanoparticles using Lantana camara leaf extract. Mater. Sci. Eng. C 2015, 49, 373-381. [CrossRef] [PubMed]

45. Jung, J.; Park, S.; Hong, S.; Ha, M.W.; Park, H.G.; Park, Y.; Lee, H.J.; Park, Y. Synthesis of gold nanoparticles with glycosides: Synthetic trends based on the structures of glycones and aglycones. Carbohydr. Res. 2014, 386, 57-61. [CrossRef] [PubMed] 
46. Gardea-Torresdey, J.L.; Parson, J.G.; Gomez, E.; Peralta-Videa, J.; Troiani, H.E.; Santiago, P.; Yacarman, M.J. Formation and Growth of Au Nanoparticles in live side Live Alfalfa Plants. Nano Lett. 2002, 2, 397-401. [CrossRef]

47. Haiss, W.; Thanh, N.T.K.; Aveyard, J.; Fernig, D.G. Determination of size and concentration of gold nanoparticles from UV-Vis spectra. Anal. Chem. 2007, 79, 4215-4221. [CrossRef] [PubMed]

48. Arunachalam, K.D.; Annamalai, S.K.; Hari, S. One-step green synthesis and characterization of leaf extract-mediated biocompatible silver and gold nanoparticles from Memecylon umbellatum. Int. J. Nanomed. 2013, 8, 1307-1315. [CrossRef] [PubMed]

49. Rodríguez-León, E.; Iñiguez-Palomares, R.; Navarro, R.; Herrera-Urbina, R.; Tánori, J.; Iñiguez-Palomares, C.; Maldonado, A. Synthesis of silver nanoparticles using reducing agents obtained from natural sources (Rumex hymenosepalus extracts). Nanoscale Res. Lett. 2013, 8, 318. [CrossRef] [PubMed]

50. Sun, Q.; Cai, X.; Li, J.; Zheng, M.; Chen, Z.; Yu, C.-P. Green synthesis of silver nanoparticles using tea leaf extract and evaluation of their stability and antibacterial activity. Colloids Surf. A Physicochem. Eng. Asp. 2014, 444, 226-231. [CrossRef]

51. Gaabour, L.H. Results in Physics Spectroscopic and thermal analysis of polyacrylamide/chitosan (PAM/CS) blend loaded by gold nanoparticles. Results Phys. 2017, 7, 2153-2158. [CrossRef]

52. Sebby, K.B.; Mansfield, E. Determination of the surface density of polyethylene glycol on gold nanoparticles by use of microscale thermogravimetric analysis. Anal. Bioanal. Chem. 2015, 407, 2913-2922. [CrossRef] [PubMed]

53. Chanda, N.; Shukla, R.; Zambre, A.; Mekapothula, S.; Kulkarni, R.R.; Katti, K.; Bhattacharyya, K.; Fent, G.M.; Casteel, S.W.; Boote, E.J.; et al. An effective strategy for the synthesis of biocompatible gold nanoparticles using cinnamon phytochemicals for phantom CT imaging and photoacoustic detection of cancerous cells. Pharm. Res. 2011, 28, 279-291. [CrossRef] [PubMed]

54. Rouhana, L.L.; Jaber, J.A.; Schlenoff, J.B. Aggregation-resistant water-soluble gold nanoparticles. Langmuir 2007, 23, 12799-12801. [CrossRef] [PubMed]

55. Huang, T.H.; Chen, C.L.; Hung, C.J.; Kao, C.T. Comparison of antibacterial activities of root-end filling materials by an agar diffusion assay and Alamar blue assay. J. Dent. Sci. 2012, 7, 336-341. [CrossRef]

56. Katerere, D.R.; Eloff, J.N. Anti-bacterial and anti-oxidant activity of Hypoxis hemerocallidea (Hypoxidaceae): Can leaves be substituted for corms as a conservation strategy? S. Afr. J. Bot. 2008, 74, 613-616. [CrossRef]

57. Nhung, N.; Thuy, C.; Trung, N.; Campbell, J.; Baker, S.; Thwaites, G.; Hoa, N.; Carrique-Mas, J. Induction of Antimicrobial Resistance in Escherichia coli and Non-Typhoidal Salmonella Strains after Adaptation to Disinfectant Commonly Used on Farms in Vietnam. Antibiotics 2015, 4, 480-494. [CrossRef] [PubMed]

58. Manosalva, L.; Mutis, A.; Urzúa, A.; Fajardo, V.; Quiroz, A. Antibacterial activity of alkaloid fractions from berberis microphylla G. Forst and study of synergism with ampicillin and cephalothin. Molecules 2016, $21,76$. [CrossRef] [PubMed]

59. Hakanen, A.; Huovinen, P.; Kotilainen, P.; Siitonen, A.; Jousimies-Somer, H. Quality control strains used in susceptibility testing of Campylobacter spp. J. Clin. Microbiol. 2002, 40, 2705-2706. [CrossRef] [PubMed]

60. Nasreen, M.; Sarker, A.; Malek, M.A. Prevalence and Resistance Pattern of Pseudomonas aeruginosa Isolated from Surface Water. Adv. Microbiol. 2015, 5, 74-81. [CrossRef]

61. Chwalibog, A.; Sawosz, E.; Hotowy, A.; Szeliga, J.; Mitura, S.; Mitura, K.; Grodzik, M.; Orlowski, P.; Sokolowska, A. Visualization of interaction between inorganic nanoparticles and bacteria or fungi. Int. J. Nanomed. 2010, 5, 1085-1094. [CrossRef] [PubMed]

62. Rai, M.; Yadav, A.; Gade, A. Silver nanoparticles as a new generation of antimicrobials. Biotechnol. Adv. 2009, 27, 76-83. [CrossRef] [PubMed]

63. Piruthiviraj, P.; Margret, A.; Priyadharsani, P. Gold nanoparticles synthesized by Brassica oleracea (Broccoli) acting as antimicrobial agents against human pathogenic bacteria and fungi. Appl. Nanosci. 2016, 6, 467-473. [CrossRef]

64. Ahmad, B.; Hafeez, N.; Bashir, S.; Rauf, A. Mujeeb-ur-Rehman Phytofabricated gold nanoparticles and their biomedical applications. Biomed. Pharmacother. 2017, 89, 414-425. [CrossRef] [PubMed]

65. Mmola, M.; Le Roes-Hill, M.; Durrell, K.; Bolton, J.J.; Sibuyi, N.; Meyer, M.E.; Beukes, D.R.; Antunes, E. Enhanced antimicrobial and anticancer activity of silver and gold nanoparticles synthesised using Sargassum incisifolium aqueous extracts. Molecules 2016, 21, 1633. [CrossRef] [PubMed] 
66. Raza, M.; Kanwal, Z.; Rauf, A.; Sabri, A.; Riaz, S.; Naseem, S. Size- and Shape-Dependent Antibacterial Studies of Silver Nanoparticles Synthesized by Wet Chemical Routes. Nanomaterials 2016, 6, 74. [CrossRef] [PubMed]

67. Khalil, M.M.H.; Ismail, E.H.; El-Baghdady, K.Z.; Mohamed, D. Green synthesis of silver nanoparticles using olive leaf extract and its antibacterial activity. Arab. J. Chem. 2014, 7, 1131-1139. [CrossRef]

68. Samejo, M.Q.; Sumbul, A.; Shah, S.; Memon, S.B.; Chundrigar, S. Phytochemical screening of Tamarix dioica Roxb. ex Roch. J. Pharm. Res. 2013, 7, 181-183. [CrossRef]

69. Obeid, L.; Linardic, C.; Karolak, L.; Hannun, Y. Programmed cell death induced by ceramide. Science 1993, 259, 1769-1771. [CrossRef] [PubMed]

70. Wang, H.; Wang, F.; Tao, X.; Cheng, H. Ammonia-containing dimethyl sulfoxide: An improved solvent for the dissolution of formazan crystals in the 3-(4,5-dimethylthiazol-2-yl)-2,5-diphenyl tetrazolium bromide (MTT) assay. Anal. Biochem. 2012, 421, 324-326. [CrossRef] [PubMed]

71. Naimi, M.; Khaled, M.B. Exploratory Tests of Crude Bacteriocinsfrom Autochthonous Lactic Acid Bacteria against Food-Borne Pathogens and Spoilage Bacteria Exploratory Tests of Crude Bacteriocinsfrom Autochthonous Lactic Acid Bacteria against Food-Borne Pathogens and Spoilage Bact. World Acad. Sci. Eng. Technol. 2014, 8, 113-119.

(C) 2017 by the authors. Licensee MDPI, Basel, Switzerland. This article is an open access article distributed under the terms and conditions of the Creative Commons Attribution (CC BY) license (http:// creativecommons.org/licenses/by/4.0/). 